Printed in Great Britain

\title{
FURTHER OBSERVATIONS ON SMALL GREEN FLAGELLATES WITH SPECIAL REFERENCE TO POSSIBLE RELATIVES OF CHROMU- LINA PUSILLA BUTCHER
}

By I. Manton

Botany Department, Leeds University

AND M. PARKE

The Plymouth Laboratory

(With total of 59 Figures on Plates I-IX and in text)

\section{CONTENTS}

\begin{abstract}
Introduction . . $\quad 275$
Observations with the electron microscope on Micromonas squamata sp.nov. . $\quad$. $\quad 277$

Observations with the light microscope on Micromonas squamata sp.nov. . . $\quad$. 283

Observations with the electron microscope on Pedinomonas tuberculata (Vischer) Gams 285

Observations with the light microscope on Pedinomonas tuberculata (Vischer) Gams 287

Further observations with the light microscope on Micromonas (Chromulina) pusilla

(Butcher) comb.nov. . . . . . . . . . . . . . . $\quad 288$

Summary of the taxonomic conclusions with diagnoses $\quad . \quad$. $\quad . \quad . \quad . \quad 2 \quad 289$

General discussion . . . . . . . . . . . . . . . . . 293

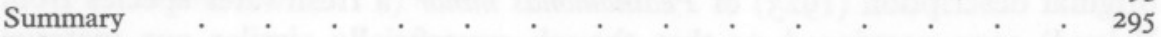

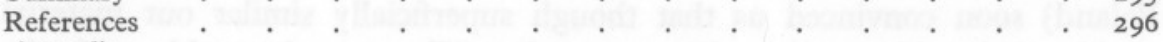

Appendix

Data on the distribution of Micromonas pusilla (Butcher) Manton \& Parke . . $\quad 297$

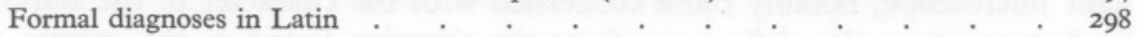

\section{INTRODUCTION}

The observations to be recorded here have been carried out primarily for the purpose of clarifying the taxonomic position and naming of the small organism previously known as Chromulina pusilla Butcher. This had been shown (Manton, I959a) to possess the pigments and fine structure appropriate to a position in or near the Chlorophyceae but quite inappropriate to a position within the Chrysophyceae to which the genus Chromulina properly belongs. Before selecting a new generic name, it was highly desirable to make some comparative electron microscopical observations on authentically named material of appropriate kinds since the fallibility of the light microscope for study of organisms of this order of size $(\mathrm{I}-3 \mu)$ had been all too clearly exposed. A search was therefore made for a representative or representatives of the only genus of green flagellates known to us from 
the literature to possess a single posteriorly directed flagellum, namely Pedinomonas.

No species of Pedinomonas has so far been encountered among flagellates isolated from the sea at Plymouth, and most of those described in the literature have been from fresh water. The Culture Collection at Cambridge, however, contains two species referred to this genus, one a recent isolation from brackish water made by E. A. George who had provisionally identified it as Pedinomonas minor Korsch., and the other a freshwater species, P. tuberculata (Vischer) Gams.

When these two species were investigated electron microscopically it at once became apparent that they were so unlike each other that they could not possibly be regarded as representatives of one genus. This rather disconcerting discovery necessitated close attention to the taxonomic credentials of the two cultures since one showed many more points of resemblance to Chromulina pusilla Butcher than the other and therefore the correct allocation of the name Pedinomonas was a matter of critical importance.

There proved to be a substantial difference between the two cultures in the authenticity of the specific names attributed to them. The original culture of $P$. tuberculata had been presented to the Cambridge collection by the describer of the species and it still agrees with the published description (Vischer, 1945, 1949) in all details ascertainable with the light microscope; its specific identity cannot therefore be called in question. The other culture was, however, a recent isolate from British estuarine waters which had been named provisionally from the literature. Close comparison with Korschikov's original description (1923) of Pedinomonas minor (a freshwater species from Poland) soon convinced us that though superficially similar our material could not be this species. Moreover, the differences detectable with the light microscope, notably those concerned with the character of the starchy food store, were also differences from the situation found in the culture of $P$. tuberculata. Since $P$. minor Korschikov itself is generally assumed to be the type species of Pedinomonas we are forced to conclude that the material supplied to us under this provisional name is not only not this species but is a new and undescribed species of an, at present, untypified genus.

The fine structure of our new species is, however, similar in many respects to that of Chromulina pusilla Butcher, allowance being made for a difference in cell size. There are also substantial morphological differences, notably in the long hair point terminating the flagellum in the latter and the very unusual covering of scales on the flagellar surface in the former; but as long as we have, as at present, only one species of each type on record, and since some of the characters in which the two species differ most from each other are completely invisible with the light microscope, it seems not unreasonable in the present state of knowledge to regard these differences as specific and not as generic criteria. It is then possible to construct a new 
generic diagnosis which will separate both these species from Pedinomonas minor on light microscope characters and from P. tuberculata on light microscope and electron microscopical characters.

We therefore propose to describe our new species as Micromonas squamata sp.nov., referring it to Micromonas gen.nov. of which M. pusilla (Butcher) comb.nov. will be the type. In designating $M$. pusilla and not $M$. squamata as the type species of Micromonas we are hoping to safeguard M. pusilla from further name changes should it become necessary in the future to subdivide this genus.

Our observations contribute only indirectly to an understanding of Pedinomonas itself since we still lack electron microscopical information about the type species. We therefore propose to limit the account of $P$. tuberculata to the minimum necessary to substantiate our view that generic separation from Micromonas is essential. It will be possible to deal briefly with M. pusilla since all the electron microscopical facts have already been placed on record in Manton (1959a). Our new species, M. squamata, will however be described as fully as is normally necessary in dealing with a new species, and since the fine structure has in this case been of critical importance in indicating the probable affinities we propose, in the account which follows, to present the electron microscopical evidence first. To meet the needs of the light microscopists, however, and to facilitate cross-reference we have supplied a table (p. 292) listing all the more important specific characters of all three species and have assembled together (Pl. IX and p. 29I) all the photographs and drawings made with the light microscope instead of following our usual practice of grouping these beside the electron micrographs of the species to which they refer.

We are able to dispense with a special section on material and methods since the methods used are exactly the same as in our previous studies on marine flagellates (Parke, Manton \& Clarke, I955, 1956, I958, I959; Manton, I959a) and the few additional details about our sources of material will be inserted with the specific descriptions.

\section{OBSERVATIONS WITH THE ELECTRON MICROSCOPE ON MICROMONAS SQUAMATA SP.NOV. \\ External morphology}

Low-power views of intact cells are uninformative except as evidence of size (Fig. I). The single posteriorly directed flagellum is about $12 \mu$ long and though it is sometimes accompanied by a second, or even a third (Fig. 2) or fourth flagellum, such supernumeraries being of any length from very short to equal, there is no doubt that these all relate to growth stages of cells in division or to giant cells representing double-divisions. In normal undivided cells, which make up the majority in any culture, only one flagellum is present. 
At higher magnifications (Figs. 3-6, 7-8) the scales and other surface appendages become visible. Almost always the arrangement of scales is disturbed by the act of drying the preparation though they commonly remain in close proximity to the surface from which they have fallen. These surfaces include not only the body of the cell but the entire length of all flagella from their base to extreme tip as may be seen in the various specimens included in Figs. 3-6. Only one of the five individual flagella depicted, namely that of Fig. 5, shows the scaly covering intact. In this particular specimen the flagellar axis has shrunk in drying and has therefore drawn away from the tubular sheath of scales which covers it. The scales themselves in this sheath are, however, still in their original positions and the regular imbrication over the entire surface is a striking feature; the few loose scales present in the field near this flagellum come almost certainly from the body of the same cell.

The fine structure of the scales is best shown in Figs. 7 and 8. There is a considerable range of sizes on any one cell, but all show a highly characteristic spider's-web pattern which we have not previously encountered on the other organisms described by us.

In addition to scales, many flagella also show hairs of an unusual kind. They are sometimes present in abundance on both sides of the flagellum and others emerge from the tip as in Fig. 4. The lateral hairs seem to fall off very

\section{Explanation of Plates I-VI \\ Micromonas squamata sp.nov.}

I

Fig. I. A dried cell photographed with the light microscope. $\times$ I000.

Fig. 2. A double-division cell with three flagella photographed with the light microscope. $\times$ I000.

Fig. 3. Tips of two of the flagella of fig. 2, the apex of the right flagellum damaged, that of the left flagellum intact, both showing a layer of detached scales throughout their length. Electron micrograph S 702.15, $\times 15,000$.

Fig. 4. Tip of another flagellum to show presence of hairs as well as scales. Electron micrograph S $668 \cdot 37, \times 20,000$.

Fig. 5. Tip of an unusually well preserved flagellum with the scaly covering intact and showing their regularly imbricated arrangement. Electron micrograph $\mathrm{M}_{586.4} \times$ c. 30,000.

Fig. 6. A flagellar tip showing detached hairs and scales and three long terminal hairs replacing the attenuated apex of the left-hand specimen in fig. 3. Electron micrograph $\mathrm{H} 4867, \times 30,000$, reversed print.

\section{II}

Fig. 7. Detached hairs and scales. Electron micrograph S $680.18, \times 50,000$, reversed print.

Fig. 8. Detached scales. Micrograph $\mathrm{H} 5760, \times 70,000$, reversed print.

Fig. 9. Part of a TS of a cell with two flagella transected near it; covering of imbricated scales visible on both. Micrograph $\mathrm{H} 246, \times 30,000$.

Fig. Io. LS of a flagellum attached to the body and showing imbricated scales in position over it. Micrograph $\mathrm{H} 2833, \times 30,000$.

Figs. II, I2. Thick sections of two cells transecting the chloroplast in directions approximately at right angles; the translucent area around the core of the pyrenoid visible in both; the nucleus present only in fig. II. Micrographs S 690.24 and 20, $\times 12,000$. 

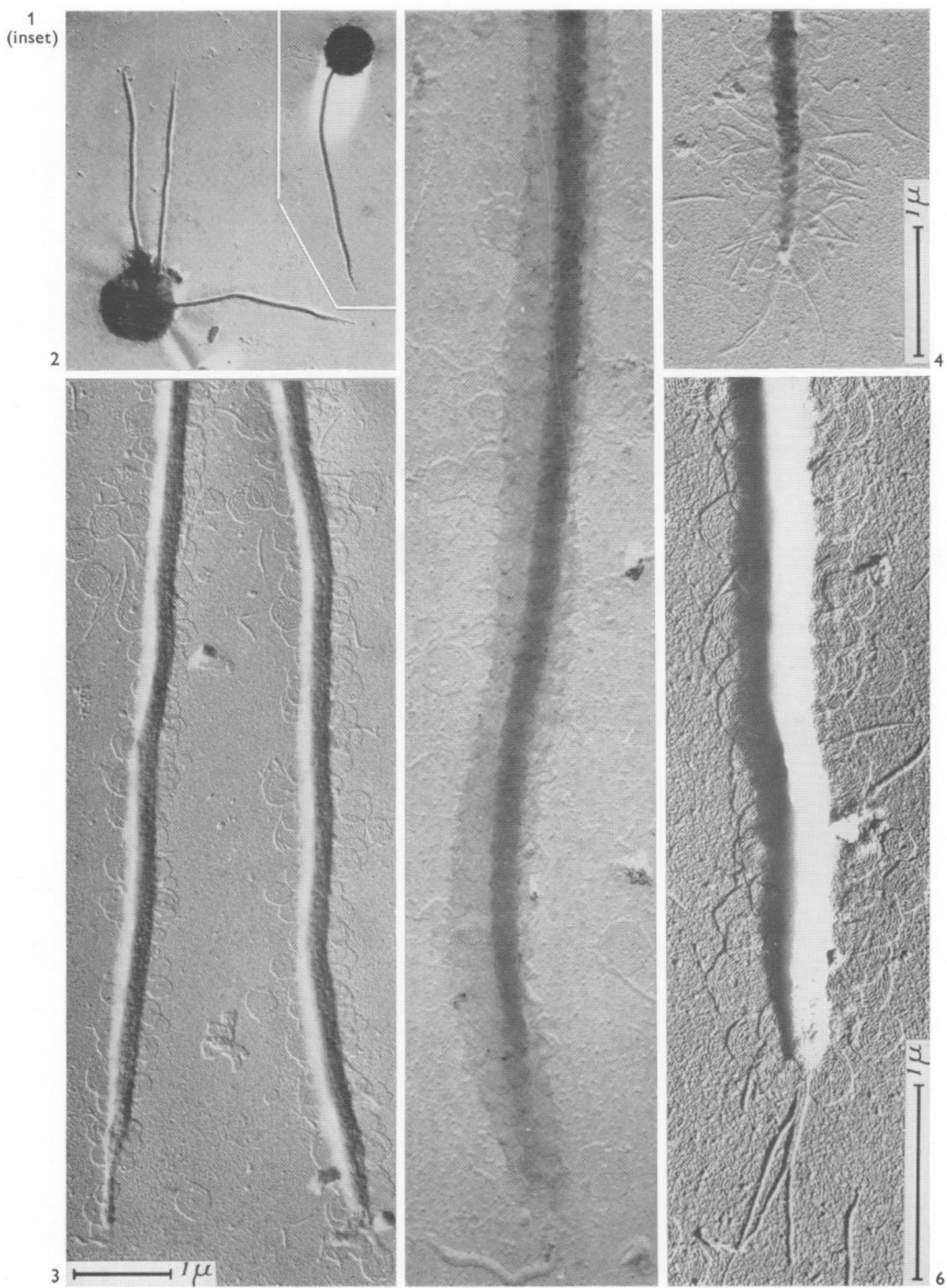

(Facing p. 278) 

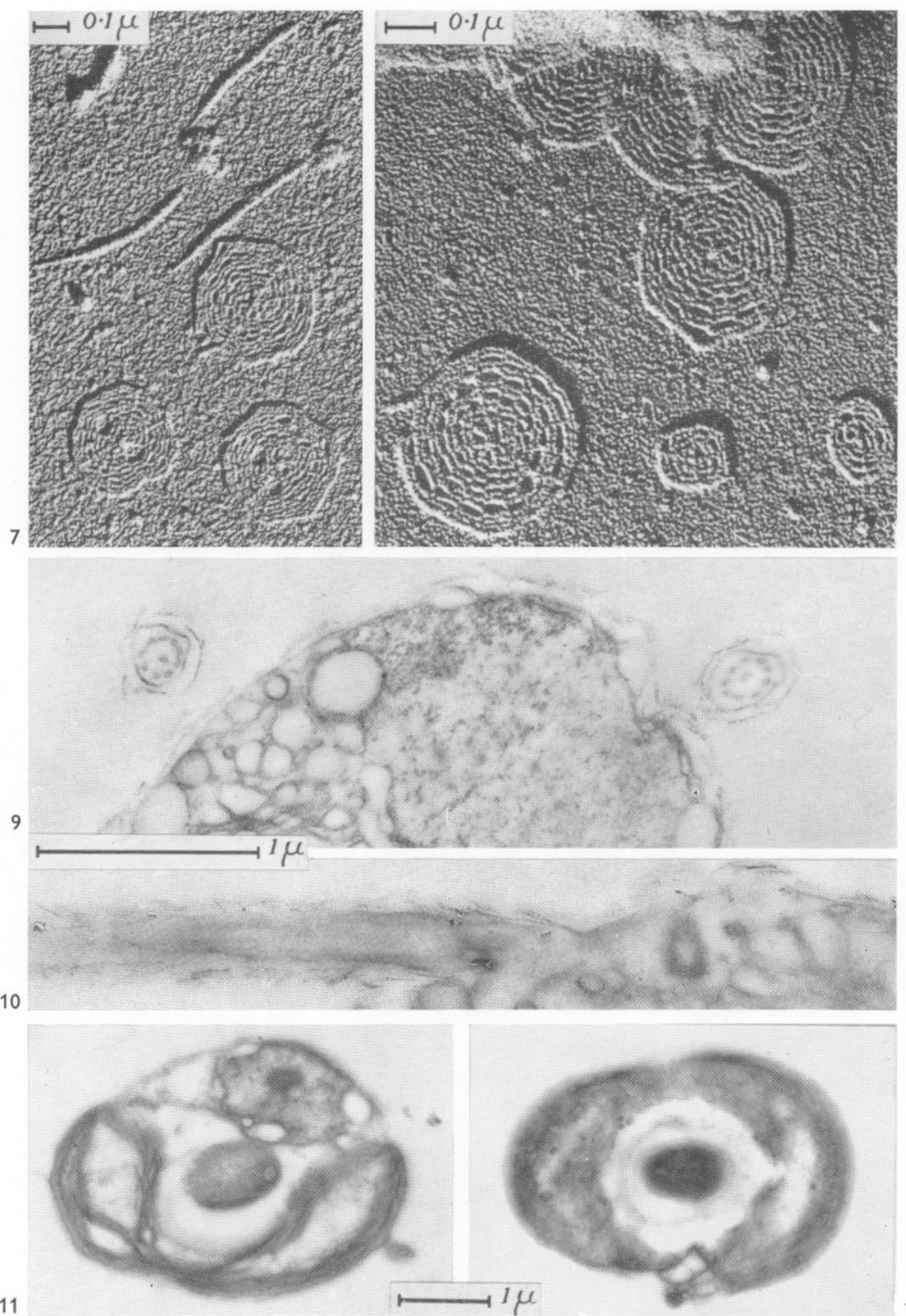

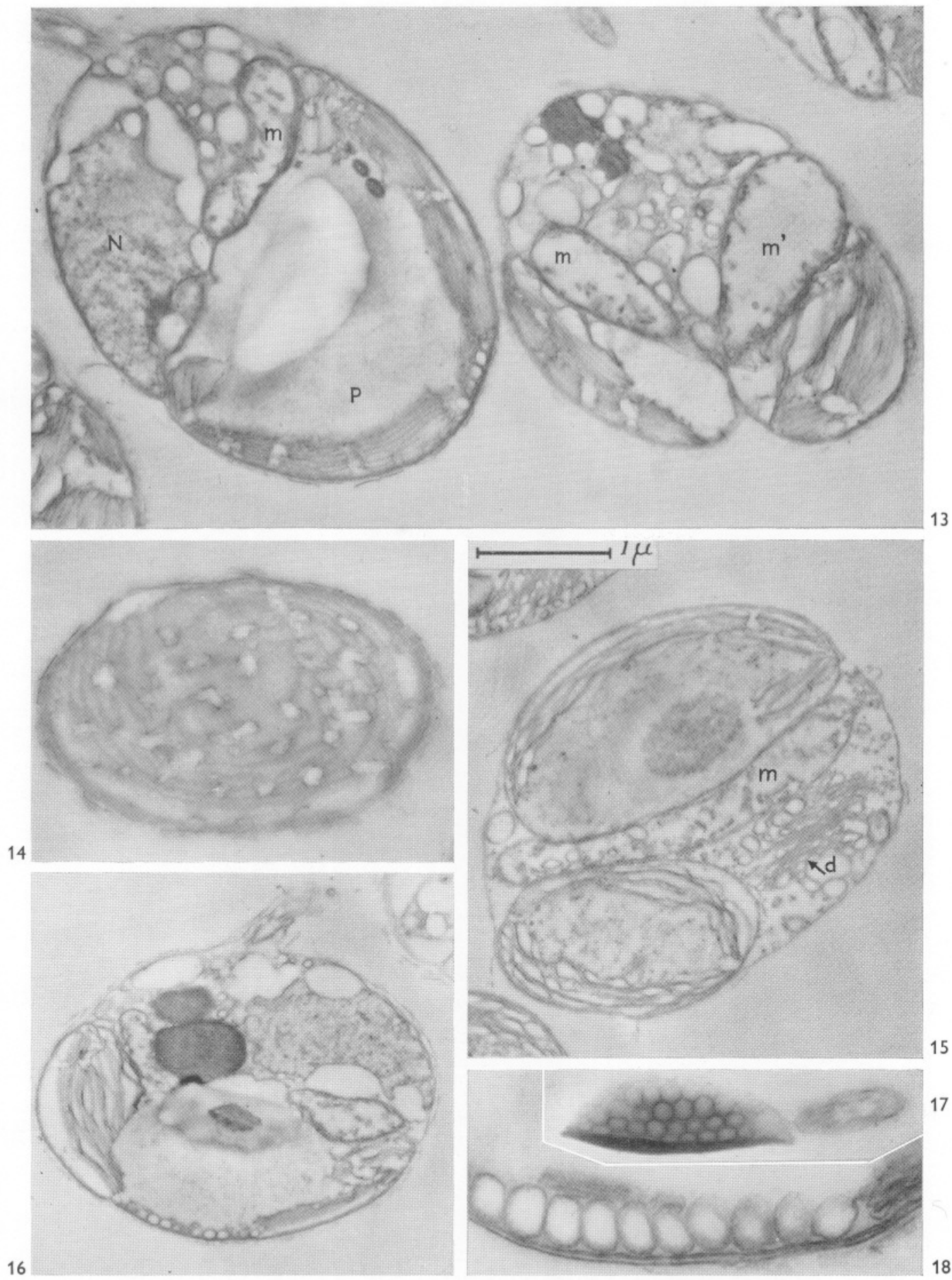


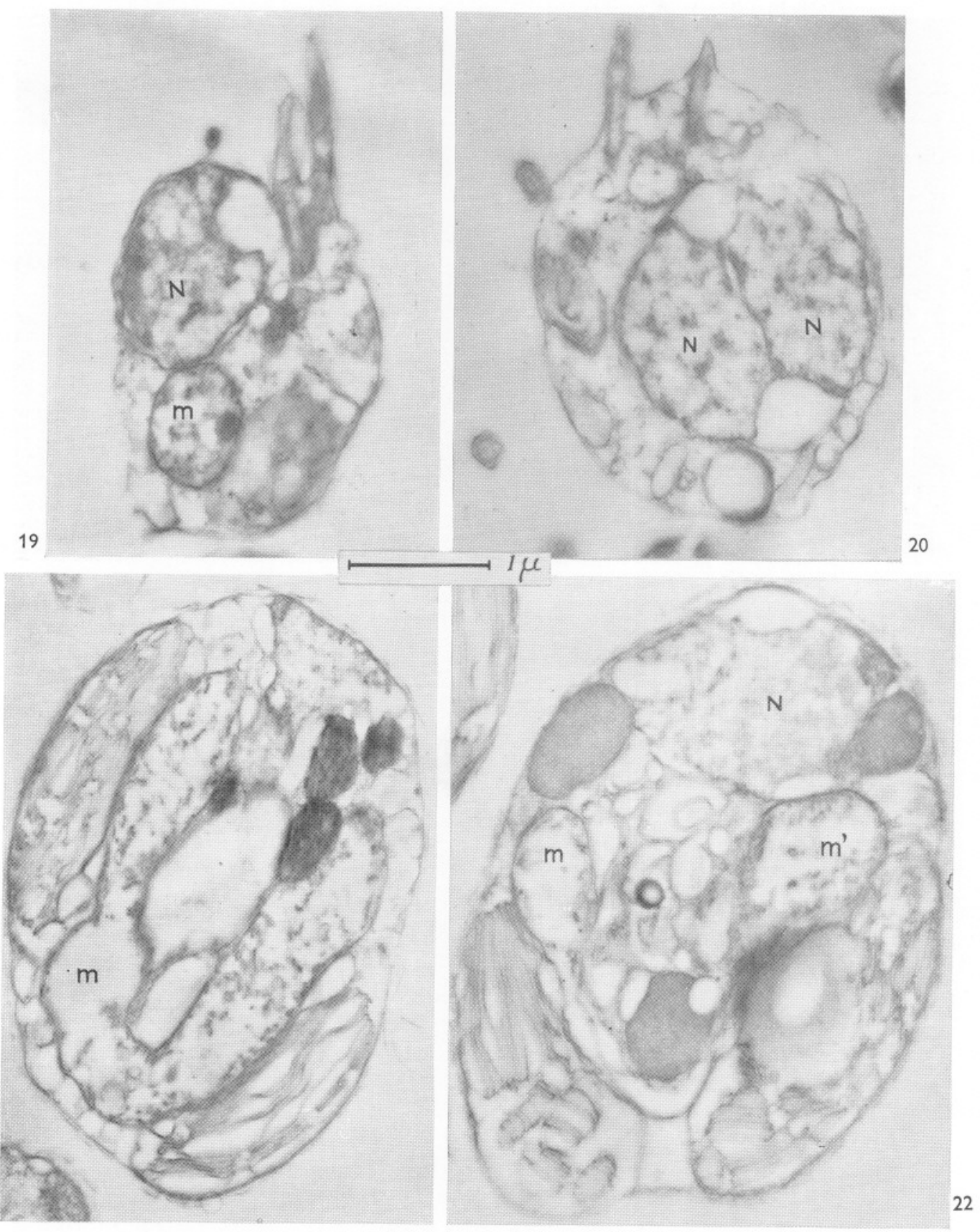



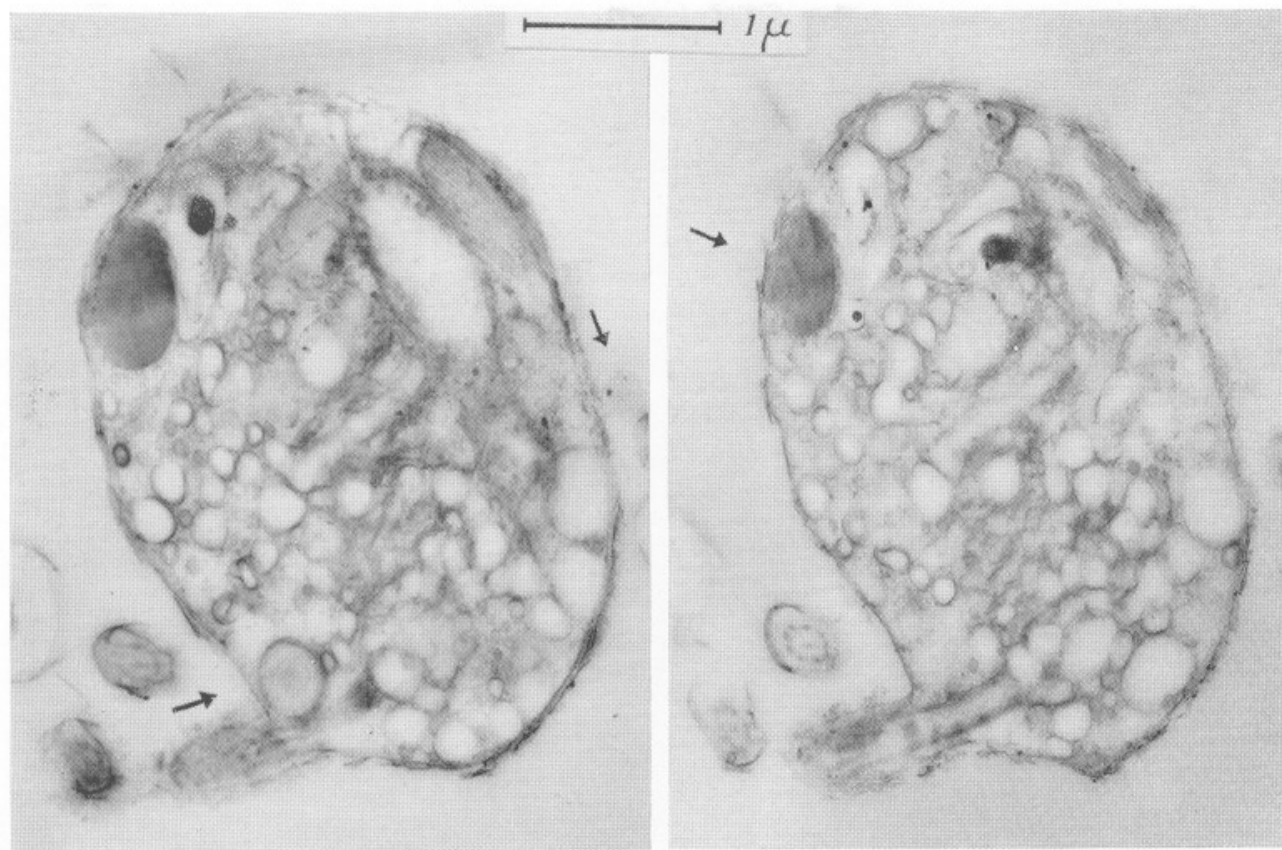

$23 a$
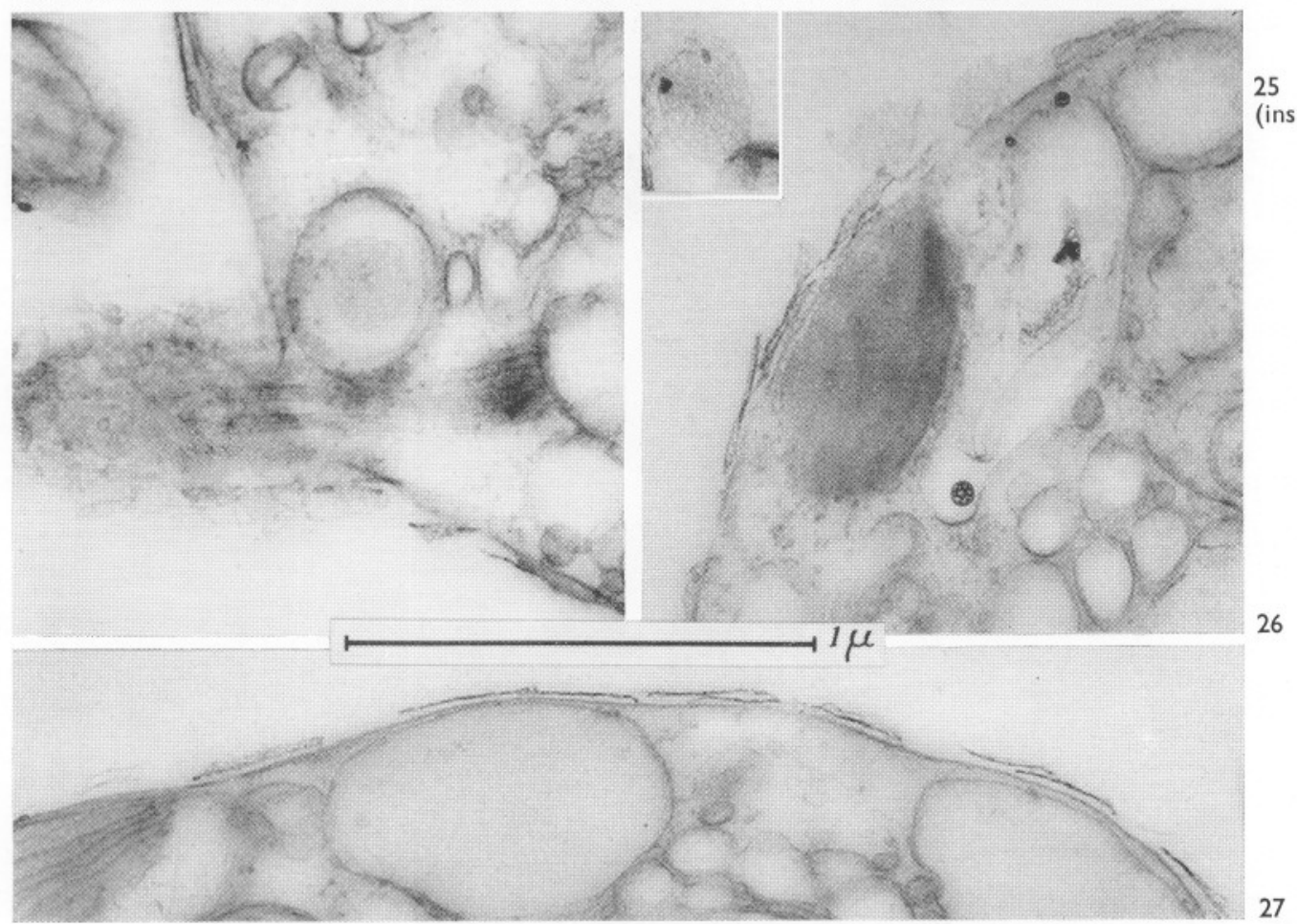


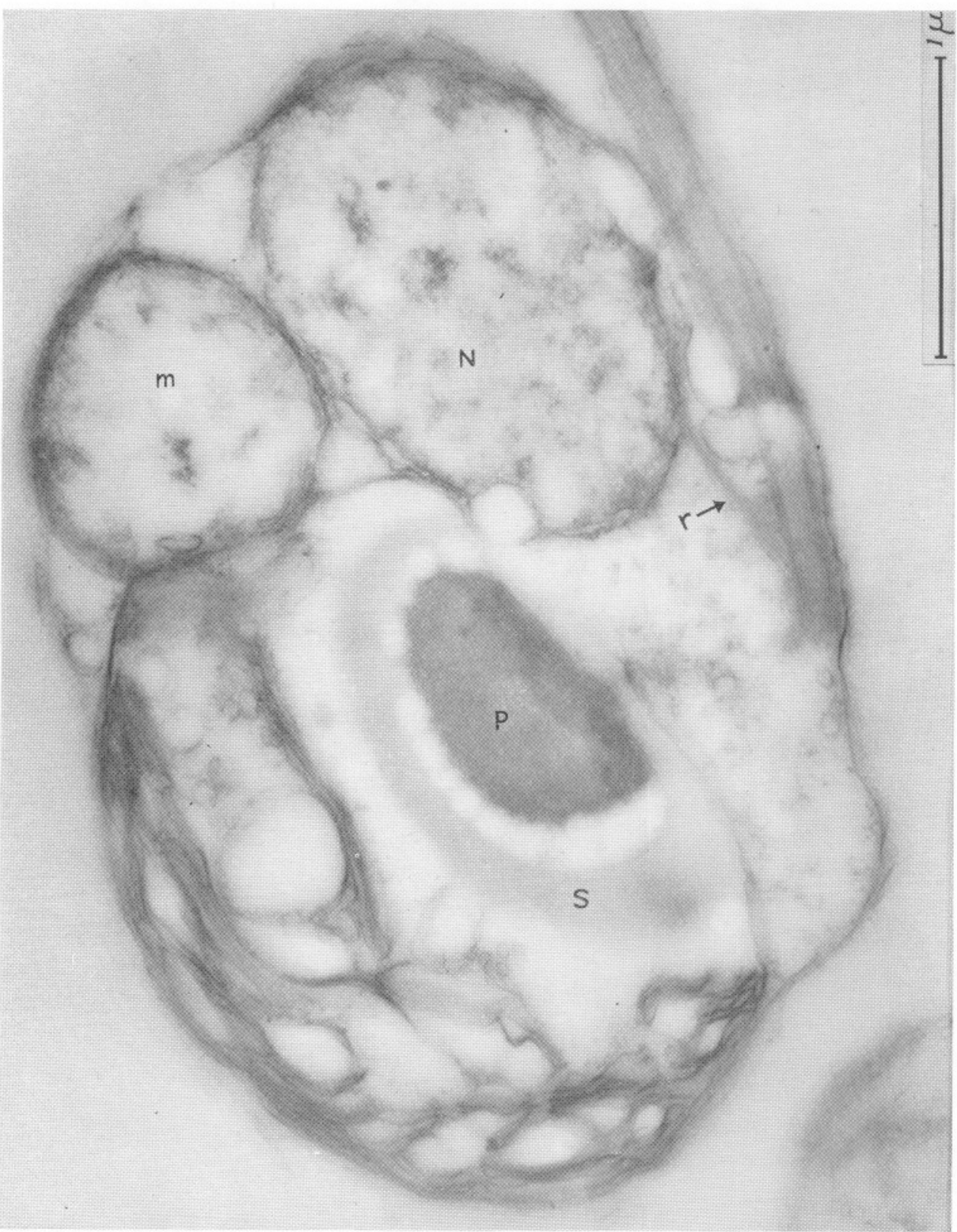

28

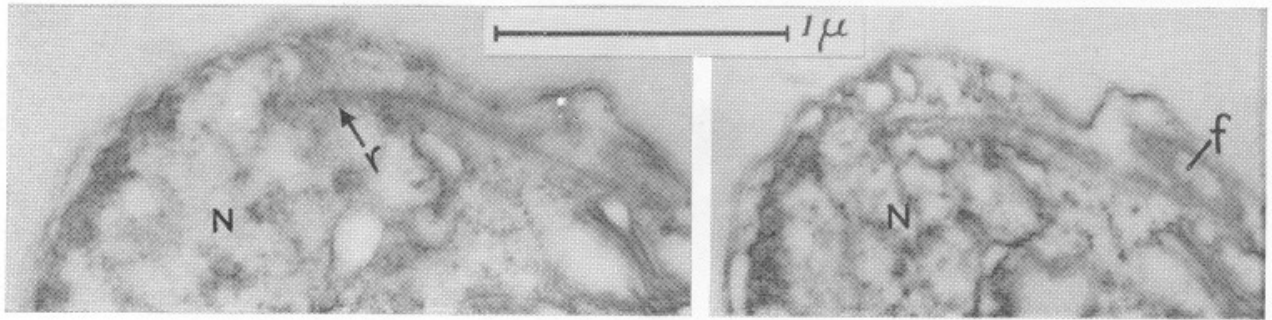




\title{
Explanation of Plates I-VI continued
}

\author{
Micromonas squamata sp.nov.
}

\section{III}

Fig. 13. Two cells, the left-most passing through the nucleus $(N)$, the mitochondrion $(m)$, the plastid $(P)$ cut near but not through the pyrenoid and showing the stacks of paired plastid lamellae near the surface with fenestrations at intervals; the right-hand cell a division stage with two lobes of a bent U-shaped mitochondrion ( $m$ and $\left.m^{\prime}\right)$ associated with the two halves of the plastid (another section of this cell, not reproduced, showed the centre part of the mitochondrion connecting the two lobes). Micrograph $\mathrm{H} \mathrm{247}$, $\times 20,000$.

Fig. 14. Tangential section near the surface of a plastid showing the fenestrations in face view. Micrograph $\mathrm{H} 5777, \times 20,000$.

Fig. 15. Part of a dividing cell showing golgi $(d)$ and a long arm of a mitochondrion $(m)$ between two plastids. Micrograph $\mathrm{H}_{5467}, \times 20,000$.

Fig. 16. A section passing through the plastid to show a structure resembling an eyespot

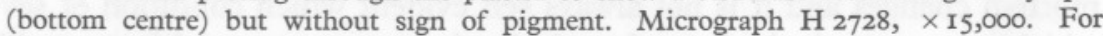
further details of eyespot region see figs. I7 and I8.

Fig. 17. Tangential section near the surface of a plastid in the region of the putative eyespot showing the close-packing of objects resembling pigment chambers, an obliquely cut flagellum near. Micrograph $\mathrm{H} 5777, \times 20,000$.

Fig. 18. More highly magnified view of plastid surface with putative pigment chambers covered by plastid double-membrane and cell body membrane. Micrograph $\mathrm{H} 2635$, $\times 50,000$.

IV

Figs. 19, 20. Two successive stages of a division showing different degrees of separation of the two flagella for the daughter-cells; two nuclei side by side visible in fig. 20. Micrographs $\mathrm{H} 2995$ and $\mathrm{H}_{3010} \times 20,000$.

Fig. 2r. Stage in a cell-division showing a very long $U$-shaped mitochondrion $(m)$ between two plastids or plastid lobes. Micrograph $\mathrm{H} \mathrm{242,} \times 20,000$.

Fig. 22. Another specimen at a stage similar to that of fig. 2I but cut in a slightly different plane and showing two plastids (or plastid lobes), a nucleus $(N)$, a $U$-shaped mitochondrion $\left(m, m^{\prime}\right)$ with the arms in contact with the two plastids, some fat bodies and vesicles with other contents in the trough of the U. Micrograph $\mathrm{H} 698, \times 20,000$.

\section{V}

Fig. $23 a, b$. Two successive sections through a flagellar insertion cut near the surface of a cell and showing disposition of vesicles and other details represented more highly magnified in figs. 24-26. Micrographs $\mathrm{H} 2647$ and $\mathrm{H} 2639, \times 20,000$.

Fig. 24. Part of the section of fig. $23 a$ near the flagellar base showing a vesicle containing a scale in full face view immediately above the flagellar insertion. Micrograph $\mathrm{H} \mathrm{2647}$, $\times 50,000$.

Fig. 25. A scale in face view outside the body for comparison with that of fig. 24 , from the region of the arrow on the right of fig. $23 a$. Micrograph $\mathrm{H} \mathrm{2647}, \times 50,000$.

Fig. 26. Part of the cell surface showing imbrication of body scales, from the field near the arrow in fig. $23 b$. Micrograph $\mathrm{H} 2639, \times 50,000$.

Fig. 27. Imbricated scales on the surface of part of another cell. Micrograph $\mathrm{H} \mathrm{2639}$, $\times 50,000$.

\section{VI}

Fig. 28. LS of a cell passing through the pyrenoid $P$, the starch shell $S$, the nucleus $N$, the mitochondrion $m$ and showing the fibrous connection $(r)$ between the base of the flagellum and the nuclear surface. Micrograph $\mathrm{H} 2986, \times 40,000$.

Fig. $29 a, b$. Two adjacent sections through another specimen showing the fibrous connection $(r)$ from the flagellar base $(f)$ ending on the nuclear surface $(N)$. Micrographs $\mathrm{H}_{5459}$ and H 546I, $\times 30,000$. 
easily, but even when none are retained on the flagellum itself they are always to be found scattered on the field in the neighbourhood, e.g. Fig. 3, top centre. It seems necessary to believe therefore that they are normal structural features and not fixation artifacts.

The average length of the lateral hairs is of the order of half a micron and their width approximately $200 \AA$; they are therefore relatively coarse, considerably more so than bacterial flagella. They are usually slightly curved with one end attenuated; this end appears to be that by which the hair is attached to the flagellum. These features are well seen on some of the detached hairs included in the field of Fig. 7.

The tuft of hairs at the tip of the flagellum is perhaps of a different nature. The tips of flagella in general are known to be specially sensitive to postmortem changes and it is not always self evident which condition of several which may occur is the least altered. In the present material it seems likely that the apex of the left-hand flagellum of Fig. 3 is in fact in the most undamaged state since it corresponds in general shape to the normal condition in many other organisms. On the right-hand flagellum of Fig. 3 the tip is partly broken away, while the abrupt termination of the flagellar column immediately below the terminal tuft of three hairs in Fig. 6 suggests that these particular hairs may perhaps be part of the distal extremity of the flagellar axis from which the outer skin has been removed leaving three of the longest component fibrils within it exposed. If this interpretation is correct the terminal hairs would here correspond to the internal parts of the attenuated distal apex of the left-hand flagellum of Fig. 3; if incorrect it would be necessary to assume that a terminal garniture of three hairs has in fact been present on the tips of all these flagella but in the case of those in Fig. 3 has fallen off. The first alternative is the more probable.

\section{Internal structure}

A preliminary view of most of the essential body organs can perhaps best be obtained from the most highly magnified section, reproduced in Fig. 28. This is comparable in attitude and plane of cutting with Fig. II of Manton (1959a) and the strong resemblance to the arrangement and structure of the cell of Chromulina pusilla Butcher will at once be apparent if the two are examined together. There is the same large plastid with superficial lamellations and conspicuous eccentric pyrenoid with dark central contents surrounded by shells of lighter material. There is the same single mitochondrion, and the positions relative to the flagellum of both these organs and of the nucleus are also comparable. The cells of our present species are, however, considerably larger $(3-6 \cdot 5 \mu$ instead of $\mathrm{I}-3 \mu)$ and therefore certain features, notably the fibrous root connecting the base of the flagellum with the surface of the nucleus, can be demonstrated here relatively easily though looked for in vain in the smaller organism. This root is visible in Fig. 28, and two adjacent 
sections of another specimen are reproduced in Figs. $29 a$ and $b$. The root undoubtedly terminates on the nuclear surface without either passing beyond or penetrating it. The distal tip is perhaps covered by a spirally wound sheath since diagonal lines sloping in opposite planes are detectable in the two sections (Figs. 29a,b).

The only other constant organs not included in Fig. 28 are fat bodies, seen incidentally in several other sections, notably Figs. I3, I6, 2 I and 22, and golgi areas (dictyosomes), one of which is indicated in Fig. 15. A single dictyosome is always present near the flagellar base, as in the previous species.

Within these various organelles certain additional structural details deserve attention. The structural arrangement within the plastid is perhaps more clearly revealed by the two thick sections cut in planes approximately at right angles to each other included in Figs. II and 12 which amplify previous information on the general shape and distribution of storage and pigment materials. The thinner sections of Figs. $\mathrm{I}_{3}$ and $\mathrm{I}_{4}$ add further details of the pigmented layers. Thus in Fig. I3 (left) the section misses the pyrenoid but passes perpendicularly through the pigmented layers showing them to be stacks of paired lamellae interrupted at intervals by spaces which in surface view (Fig. 14) appear as roughly isodiametric holes scattered in a fairly uniform distribution over the surface.

Figs. I6-I8 show some of the details associated with the region resembling an eyespot in the middle of the outer surface of the plastid. Here the ordinary lamellae are replaced by a layer of close-packed cylindrical chambers with well marked walls resembling those encountered in eyespots of other organisms, e.g. Fucus (Manton \& Clarke, 1956), though here with translucent contents suggesting that special pigmentation was either absent at the time of fixation or has dissolved out.

The region of the putative eyespot is very suitable for demonstrating the compound nature of the plastid membrane (Fig. I8). Its over-all thickness is somewhat greater than that of the cell-body membrane overlying it which is also compound (better seen underlying the scales in Fig. 27).

The single mitochondrion, which is in itself one of the more striking features by which this species resembles Chromulina pusilla Butcher, is very strikingly shown in the early division stages during which the mitochondrion may become very long and bent into a $U$ or $V$ shape before dividing. Different manifestations of this are included in Figs. 13, 21 and 22, but it should be noted that if the plane of section does not coincide with the plane of elongation of the mitochondrion the two ends may be found so far apart (e.g. Fig. 13) that at first they might be mistaken for two separate organelles. That this is not so is clearly indicated by the constant position of the component parts lying in what is effectually a groove between the plastid rim and the centre bulge caused by the pyrenoid and marking the eventual place of cleavage. The number of cristae, i.e. internal projections within the mitochondrion, 
is far larger than in C. pusilla; they appear to be somewhat flattened tubes, rather short and not displaying the peculiar curved paths characteristic of the other species (Manton, I959a).

The most important new facts from the point of view of a general understanding of algae are those associated with the origin of the scales. It is probable that the scales are slightly mineralized since, though no thicker than the scales of the species of Chrysochromulina described by us, they are slightly more opaque than these when seen in section (e.g. Fig. 27), appearing distinctly denser than the cell membrane over which they lie. This circumstance makes them slightly more conspicuous in various planes of section than the unmineralized scales more familar to us and it is probably for this reason that the following observations as to their mode of formation have been obtainable. It had previously been thought probable that scales of any kind when encountered on the surface of a 'naked' cell would have been produced in one way or another from the surface membrane underlying them. That this is not so here is however proved by finding completed scales inside the cell as in Fig. 24 where a perfect spider's-web scale is encountered in face view in the centre of a large vesicle below the cell surface near the insertion of the flagellum. Figs. $23 a$ and $b$ are introduced to show the exact position on the specimen from which this detail was taken and other scales outside the body or in position on it are illustrated in Figs. 24-26. Since all attempts to demonstrate phagotrophic feeding by this species have proved vain it is necessary to conclude that internal scales are part of a developmental process and have not been swallowed from outside.

It has not been possible to follow all the developmental details, since scales can scarcely be recognized as such in a very incomplete condition. The probable site of synthesis is, however, in the group of vesicles with contents which commonly occupies the space between the arms of a V-shaped mitochondrion in a dividing cell (Fig. 22). These vesicles contain contents of various kinds including, usually, some densely opaque material and also objects possessing a type of refringence reminiscent of that of the scales. If this is a true identification these vesicles are too large and too full of contents to be engaged in production of single scales. It therefore seems probable that the early stages are passed through in groups within these large, relatively central, vesicles, and that the transferrence of single scales into separate vesicles near the cell surface is part of the final act of deposition. If this is so the very regular imbrication of the scales covering the flagellum, already seen in Fig. 5 and detectable both in LS and TS in Figs. 9 and 10, is readily understandable as the expression of the successive opening on to the surface of a cluster of vesicles each containing one scale and arranged round the base of a growing flagellum. The great difficulty of imagining any mechanism by which scales could be produced from the apparently normal flagellar surface itself is thereby eliminated. 


\section{OBSERVATIONS WITH THE LIGHT MICROSCOPE ON MICROMONAS SQUAMATA SP.NOV.}

Examples of cells photographed with the light microscope, using dark-ground illumination, will be found grouped under one number as Fig. 40, P1. IX (facing p. 288); some are in the uniflagellate condition and the remainder are division stages with two or four flagella, unequal to equal in length. Fig. 39, P1. IX, illustrates two cells of Chromulina pusilla Butcher at the same magnification for comparison; their much smaller size has made it impossible to obtain effective photographs of the flagella by this method.

Cells of the organism that we propose to name Micromonas squamata sp.nov. can swim fairly quickly, rotating rapidly with only slight gyration and moving in straight lines for short distances, but more usually they move fairly slowly with slow rotation of the body and more pronounced gyration. They can also glide along for short distances without rotation, or they can show periods of jerking about very actively by the lashing of the flagellum. During movement, the region of the body at which the flagellum arises is always foremost. The proximal $\mathrm{I}-2 \mu$ of the flagellum becomes pulled out into what appears, when the cell is moving, to be a short stiff spine-like organ which lies in front of the body (Figs. 44-45); the remainder of the flagellum is curved sharply backwards down the side of the body to lie behind the cell. When cells are moving rapidly the flagellum appears to vibrate but when moving more slowly definite undulations can be observed; the undulations are usually small but can on occasion be large. A cell stops swimming suddenly by bringing the flagellum up with a sharp jerk of the body into a curved position round and under the body (Fig. 42), sometimes coiled twice round the body (Fig. 43), after which the cell will commonly move off in a different direction. In fission stages when a second flagellum has developed, the two behave homodynamically, both twisting round the body simultaneously when a cell stops swimming to change direction.

The region of the body close to the point of origin of the flagellum can show considerable metaboly and, in addition, fine pseudopodium-like filaments have several times been seen produced; they appear to attach to the surface of the slide but so far only cells in the incipient fission stage have been seen producing these filaments (Fig. 46).

In an actively growing culture $15 \%$ of the cells are $3 \mu$ in size, $20 \% 3.5 \mu$, $40 \% 4.0 \mu, 13 \% 4.5 \mu$, while the remaining $12 \%$ are incipient fission stages ranging from 5 to $6.5 \mu$ in size. The smallest cells (newly divided daughter-cells) may show some slight flattening of the body but the larger cells and the fission stages are more globose. The flagellum length in relation to the body size can vary from $2 \frac{1}{2}$ to 4 times the length of the body but $80 \%$ of the cells have a flagellum $3-3 \frac{1}{2}$ times the length of the body.

This organism shows a distinct phototactic reaction but there is no evidence 
of phagotrophy. In culture it is yellow-green, i.e. is similar in colour to Chromulina pusilla Butcher, and it contains, as does the latter, chlorophyll $a$, chlorophyll $b, \beta$-carotene and $\alpha$-xanthophyll (Dr G. Y. Kennedy, personal communication).

In the living cell the most obvious of the cell contents are the chloroplast with its embedded pyrenoid and, when present, the refractive lipid body or bodies. The chloroplast is situated on the side of the body opposite to that from which the flagellum arises; under the high power it appears striated with the pigmented outer region crescentic in optical section. The pyrenoid, immersed in the inner side of the chloroplast, is surrounded by a starch shell staining violet with iodine. The starch shell shows considerable variation in shape and size in different cells and it may be studied either in intact stained cells or loose among the debris taken from broken cells at the bottom of the flask. Examples of such isolated but intact starch shells are drawn in Fig. 47. When least developed the starch shell is a hollow sphere a little over $\mathrm{I} \mu$ in diameter surrounding the pyrenoid on all sides except that nearest to the unpigmented face; an isolated starch shell is therefore a hollow sphere with a hole at one pole. As the shell thickens its outline becomes more ovoid and irregular, the starch appearing to be laid down unevenly, more being deposited on the sides than in the centre but the hole on the inner plastid face never becoming covered. The largest starch shells are about $3 \mu$ in diameter.

There is usually one lipid body, about $0.5 \mu$ in diameter, situated in the cell on the side opposite to the chloroplast, but occasionally none are present. After a culture has been grown in strong light for some time additional lipid globules can be seen in the cells; there may be from $I$ to 4 and they lie against the inner face of the chloroplast. The stigma, orange-red, and oval to oblong in the surface view, measuring up to $\mathrm{I} \times 0.5 \mu$, lies centrally in the outer face of the chloroplast and is not always readily detected. A single elongated mitochondrion, $\mathrm{I} \times 0.75 \mu$ in size when stained with Janus Green, lies on the inner face of the chloroplast while the ovoid nucleus, I. $5 \times \mathrm{I} \mu$ in size, lies outside it towards the side of the cell from which the flagellum arises. The golgi area, situated close to the nucleus, stains with Janus Green to give a bluer colour than the mitochondrion. Neither the body scales nor the flagellar scales stain with cresyl blue, but the flagellar basal body can be detected after fixation with osmium tetroxide.

Asexual reproduction can occur in either the motile or non-motile phase. In the motile phase fission is usually into two daughter-cells but it is not uncommon for double-fission to occur producing three or four daughter-cells at the same time from the parent cell (Figs. 40, 48, 49). The first indications of fission are the simultaneous elongation of the stigma and pyrenoid accompanying the first appearance of the second flagellum; occasionally the stigma divides and the daughter-flagellum appears before the elongation of the pyrenoid. By the time the daughter-flagellum has nearly reached its full 
length the nucleus, mitochondrion, golgi, chloroplast, pyrenoid and stigma have divided. The daughter-flagellum is fully developed and the chloroplasts have separated before actual fission of the body commences at the flagellar pole. In the non-motile (palmelloid) phase, the cells become surrounded by what appears to be a very thin membrane lying close to the body; such cells divide into four or occasionally eight daughter-cells (Figs. 50, 5I). The apparent membrane shows up a little more clearly after treatment with Schultz's solution but its precise nature is uncertain.

If this description is compared with that of Korschikov (1923) for Pedinomonas minor the following differences from $P$. squamata should be noted: habitat in standing fresh water of inland areas in Poland and west Russia (more recently reported from similar habitats from Hungary by Fott \& Ettl (1959)), in contrast to the brackish habitat of $M$. squamata; presence of a contractile vacuole reported in $P$. minor, not detectable in $M$. squamata; the flagellum in $P$. minor considerably shorter (only $\mathrm{I} \frac{1}{2}$ times body length) than in $M$. squamata (where it is $2 \frac{1}{2}-4$ times body length); starch grains present round the pyrenoid as opposed to the continuous starch shell of $M$. squamata.

\section{OBSERVATIONS WITH THE ELECTRON MICROSCOPE ON PEDINOMONAS TUBERCULATA (VISCHER) GAMS}

\section{External morphology}

The cells of this species make very elegant preparations when dried down and they also possess an unusual capacity for informative dismemberment. One intact cell is illustrated in Fig. 30 with the tip of its plume-like flagellum shown more highly magnified in Fig. 33. The profuse garniture of very delicate hairs spread on the field on both sides of the flagellar axis are highly characteristic. They are individually so slender, however, that the bacterial flagella lying loose in various parts of the field of Fig. 3I appear coarse in comparison.

Where cells have dismembered as in Figs. $3 \mathrm{I}$ and 32, four stout roots arranged in a cruciform manner are seen to be attached to the lower end of the flagellar base. These roots have a fibrous core and a membranous covering which in some if not all exhibit conspicuous diagonal striations as of a spiral winding of alternating bands of different electron opacity. This diagonal cross-banding is clearly visible in the lowermost root of Fig. 32.

\section{Internal structure}

One morphological detail, namely, the superficial tubercles from which this species gets its name, is better seen in sections than in our whole mounts. They occur as spine-like excrescences on various parts of the body as may be seen in Figs. 34-35. These tubercles are covered by the normal body membrane and they therefore represent local deposits of material beneath the 
membrane. This material is unidentifiable by the electron microscope alone but the presence of cellulose, calcite and quartz $\left(\mathrm{SiO}_{2}\right.$ in micro-crystalline form) has been indicated by X-ray analysis by Brandenburger \& FreyWyssling (1947) and one or other of these components could be represented here. In addition, the surface membrane, which bears no resemblance in section to a normal cell wall, is covered by small spicules and traces of amorphous material among which fine particles of metallic osmium commonly become lodged as a fixation artifact. It therefore seems probable that though entirely devoid of either scales or a cell wall of algal type the membrane of this species is not completely naked on its outer side.

When viewed in section (P1. VIII) the cells of $P$. tuberculata appear strongly flattened. Internally the cell is dominated by the large starch-filled chloroplast which is here curved (see especially Fig. 37), surrounding the other cytoplasmic organs which lie in the hollow. In a section cut in another direction (Fig. 36, approximately at right angles to Fig. 37) the nucleus is seen to be strongly flattened against the outer surface of the body on one side. There are several rather small mitochondria in the hollow of the curved plastid, one conspicuous golgi body (dictyosome) near the flagellar insertion and an array of small vesicles and granular cytoplasm. A few larger vesicles containing traces of opaque fat-like material are often conspicuous, though

\section{Explanation of Plates VII and VIII \\ Pedinomonas tuberculata (Vischer) Gams}

\section{VII}

Fig. 30. A dried cell. Micrograph S 672.26, $\times 3000$.

Fig. 3I. Field containing a dismembered cell represented by an intact flagellum with four roots arranged in a cruciform manner; bacterial cells and bacterial flagella loose upon the field and appearing relatively coarse in comparison with the very fine lateral hairs on the flagellum of Pedinomonas. Micrograph S 669.30, × 10,000.

Fig. 32. Base of the flagellum and roots from another specimen showing fibrous structure in the roots and traces of cross-banding probably carried by a covering membrane on the longest of the roots shown. Micrograph S 669.29, $\times 20,000$.

Fig. 33. Tip of the flagellum of the cell of fig. 30 more highly magnified to show the details of the hairs. Micrograph S $672.28, \times 20,000$, reversed print.

Fig. 34. Section through a tubercle. Micrograph $\mathrm{H} 4957, \times 30,000$.

Fig. 35. Section through a tubercle, another specimen. Micrograph $\mathrm{H} 4985, \times 40,000$.

\section{VIII}

Fig. 36. Section of a cell showing parts of all the main organelles; nucleus $(N)$, pyrenoid $(P)$ starch grains $(S)$, mitochondria $(m)$, golgi $(d)$. Micrograph H $4993, \times 40,000$.

Fig. 37. Section cut in another plane showing the curved plastid surrounding the other organelles in the hollow, the flagellar base cut transversely at the top of the section. Micrograph $\mathrm{H} 5047, \times 30,000$.

Fig. $38 a, b$. Two successive sections through a flagellar base $(f)$ in the region of a root $(r)$, to show its superficial position and close relation with the edge of the plastid; a golgi area $(d)$ also included in Fig. 38 b. Micrographs $\mathrm{H} 498 \mathrm{r}$ and $\mathrm{H} 4978, \times 50,000$. 

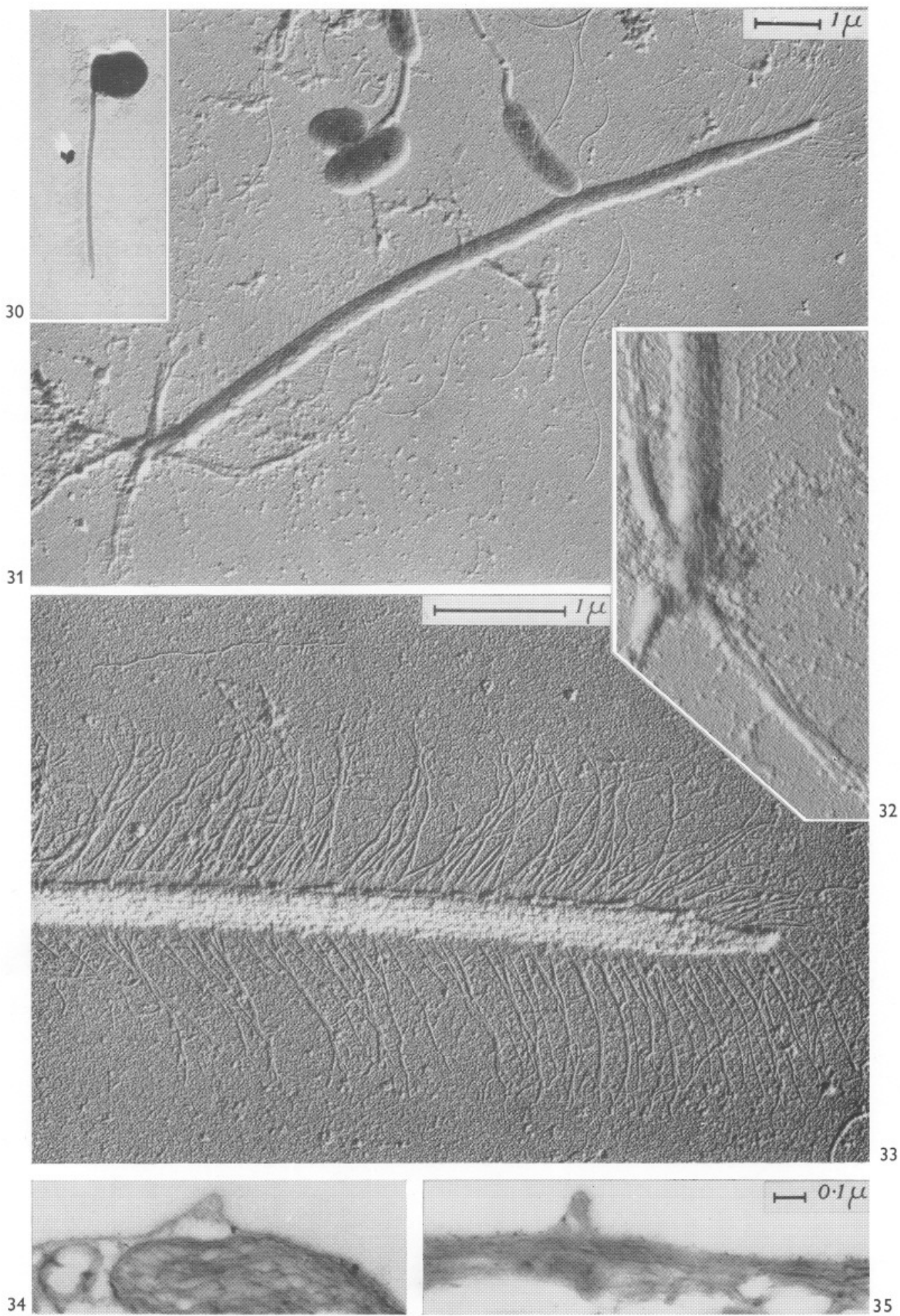

(Facing p. 286) 
J. MAR. BIOL. Ass. U.K., 39 (2)

MANTON \& PARKe. PLATE VIII

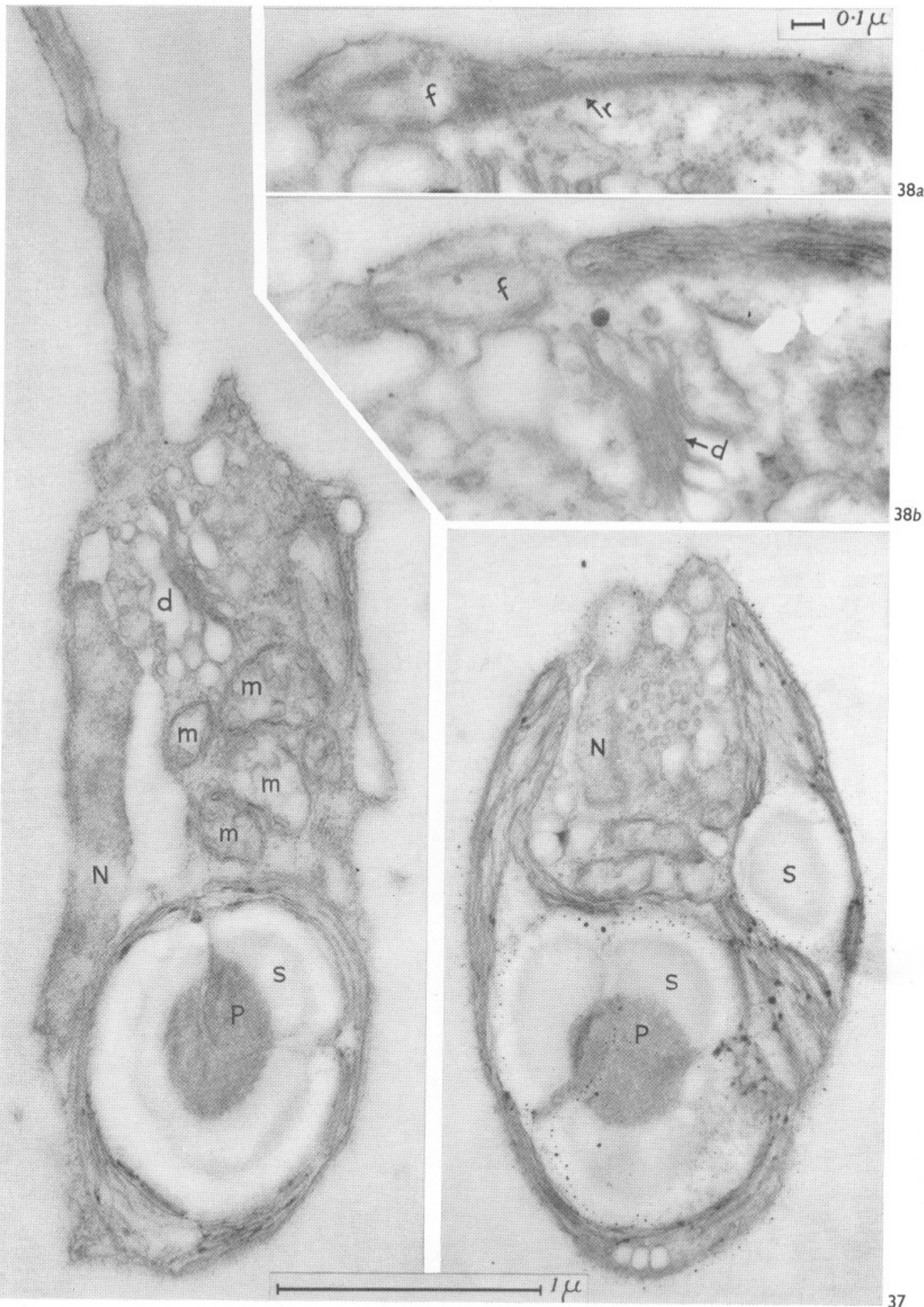


not included in the section reproduced. The cavity at first suggestive of a large vesicle on the right of the nucleus in Fig. 36 is a distortion of the perinuclear space.

Within the plastid the stacks of paired lamellae are conspicuous outside and between the starch accumulations; dark granules are conspicuous among them and there are traces of fenestrations comparable to those of Micromonas squamata here and there (Fig. 36). The pyrenoid itself has a dense core traversed by channels connected with the lamellated surface; large starch grains occupy the space between the lamellae and the core. Additional starch grains occur singly in other parts of the plastid (Fig. 37).

Some details concerning the attachment of the flagellum are illustrated in Fig. $38 a$ and $b$. The flagellum itself is situated close to one edge of the plastid, as may clearly be seen in the specimen transected in Fig. 37. Fig. $38 a$ shows the position of one of the cross-banded roots in relation to the subtending basal body $(f)$. This root $(r)$ remains close to the cell surface running along the plastid edge (cf. Fig. 38b) and apparently terminating on it (Fig. 38a). There is no sign of a direct attachment to the nucleus which in this particular specimen is situated in the direction of the bottom right-hand corner of Fig. $38 \mathrm{~b}$. The disposition of the other three roots is uncertain and it is possible that some may proceed in the direction of the nucleus, but it is probable that all are relatively superficial in position since this would adequately explain the ease with which they tear out of the cell when it dismembers.

This species thus differs from $M$. squamata in the shape of the plastid and structure of the pyrenoid, in the possession of conspicuous starch grains both in the pyrenoid and outside it, in the size, number and position of the mitochondria, in the position and shape of the nucleus, in the nature of the cell surface, and in the character and mode of attachment of the flagellum.

\section{OBSERVATIONS WITH THE LIGHT MICROSCOPE ON PEDINOMONAS TUBERCULATA (VISCHER) GAMS}

Vischer's descriptions (1945, I949) are sufficiently accurate and detailed to make it unnecessary for us to quote many new observations on P. tuberculata. The presence of chlorophyll $a$ and chlorophyll $b$ has been demonstrated by Harder \& Koch (1954), but even though both species of Micromonas also contain these pigments there is a readily perceptible difference of actual colour, $P$. tuberculata being a bright grass green both in the mass and in individual chloroplasts, whereas both species of Micromonas appear no more than yellowish green. The presence of starch in definite grains round the pyrenoid and elsewhere in the chloroplast is easily attested by staining with iodine.

A small eyespot as claimed by Vischer can sometimes be seen, ovoid in shape, $0.5^{-1} \cdot 0 \mu$ long and pale orange-red in colour, situated centrally on the 
surface of the plastid (Fig. 52). It is not, however, always detectable and the extreme insensitivity of the organism to the direction of incident light added to our inability to detect an eyespot structurally in the sections so far examined with the electron microscope suggests that perhaps the pigment spot observed may be of some other kind.

The organism swims fairly rapidly, travelling sometimes in straight lines for short distances or sometimes in circles; stops are frequent, the flagellum then curving towards the body (Fig. 54), after which the cell will move off in the same or another direction. During movement the body rotates and can show considerable gyration. The flagellar insertion is always directed backwards during swimming with the flagellum trailing (Figs. 4I, 52, 53). The insertion itself is slightly off centre (Figs. 52-54).

\section{FURTHER OBSERVATIONS WITH THE LIGHT MICROSCOPE ON MICROMONAS (CHROMULINA) PUSILLA (BUTCHER) COMB.NOV.}

The following new observations on living cells may be quoted to supplement the account of the fine structure already published (Manton, I959 $a$ ). The cells can be very fast moving, with frequent changes of direction (relative speed in culture quoted by Knight-Jones \& Walne (I95I) as fifty times the body length per second). When a cell changes direction it frequently moves round in circles for a time before swimming off in a different direction. During rapid swimming the cell travels with the rounded end, containing the chloroplast, foremost and with the clear end curved towards the side from which the flagellum arises (Fig. 55). The flagellum proper is then at right angles to the body, arising from the concave surface and with its distal long hair-point curving outwards and backwards (Figs. 55, 56); the shape of the whole cell is then strongly reminiscent of a comma. It is probable that the body does rotate when the cell is swimming very rapidly, but rotation can be seen only when movement becomes slower since there seems to be no gyration. The cells can also swim for short periods with the flagellum directed forwards (Figs. 57, 58) but the speed is then slower. This species characteristically has considerable periods of remaining in one position attached to a surface by the clear end of the body which tends to show metaboly, the cell

\section{Explanation of Plate IX}

Photographs of cells under oil immersion with the light microscope arranged for dark ground illumination, all magnified $\times$ rooo.

Fig. 39. Two cells of Micromonas pusilla (Butcher) comb.nov., the small tubercle on the right-hand cell is the flagellum, its hair-point not visible.

Fig. 40. Micromonas squamata sp.nov. A series of exposures to show the uniflagellate condition and various division stages.

Fig. 4I. Pedinomonas tuberculata (Vischer) Gams. A series of exposures to show uniflagellate cells and division stages. 

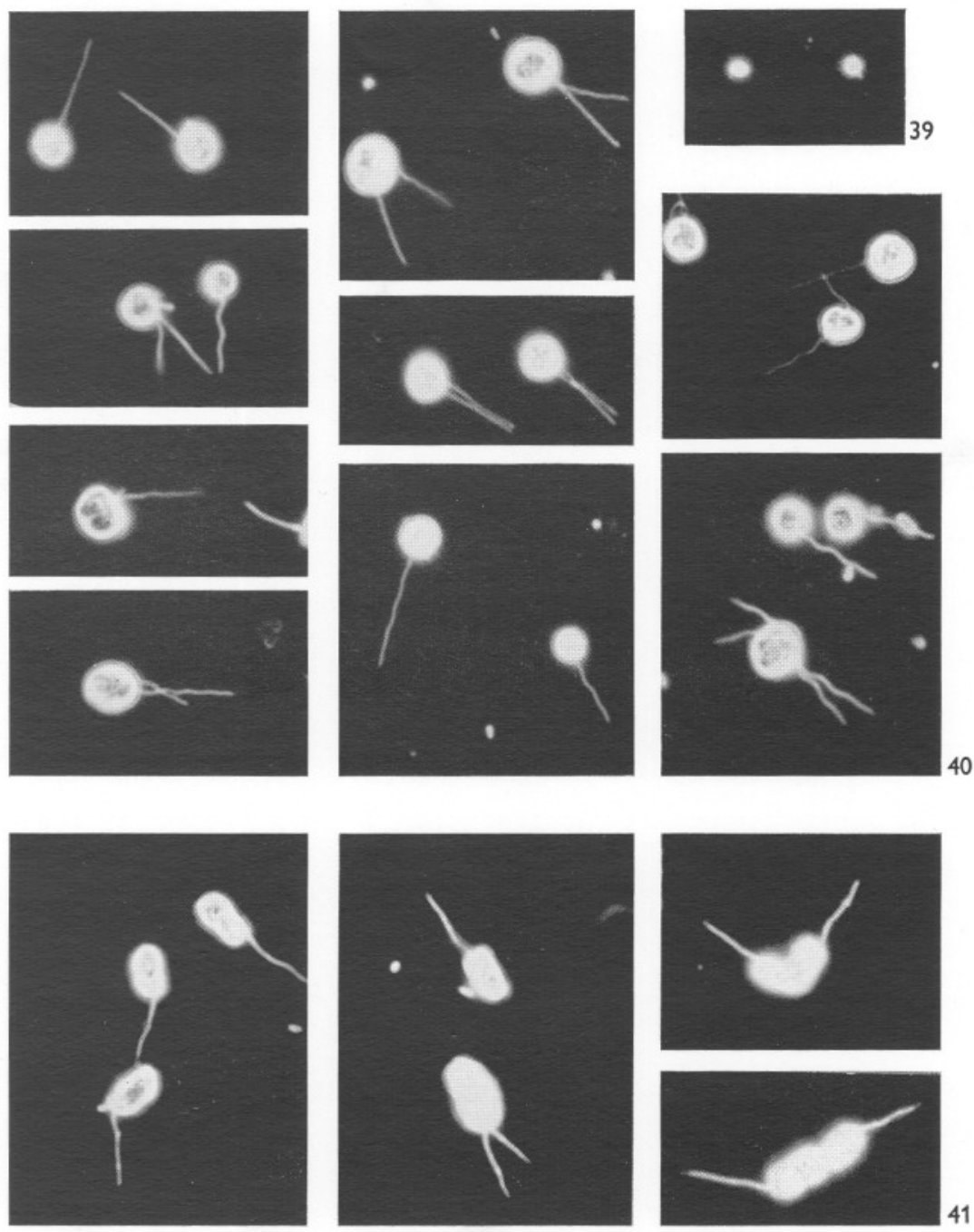

(Facing p. 288) 
meanwhile either swinging round in circles from the point of attachment (Fig. 59) or exhibiting a dithering movement which is very characteristic for this organism.

The species is strongly phototactic and is not toxic to fish (tested by Mrs B. Hepper). Motile cells in culture measure $\mathrm{I} \cdot 0-3 \cdot 0 \mu$ long $\times 0.75^{-I} \mu$ wide. Fission occurs in both motile and non-motile condition. A non-motile palmelloid phase with cells measuring $2 \cdot 5-5 \mu$ and showing a translucent area round each also occurs, the cells dividing into 2 or 4 . No trace of cellulose is detectable in either motile or non-motile phases and no positive signs of starch when tested with iodine. Signs of a sexual process have been looked for by mixing five different strains, without success.

In occurrence this marine flagellate is very widespread; it has been recorded from surface samples taken from estuaries, creeks and the open sea around the British Isles (Knight-Jones, I951, I952; Knight-Jones \& Walne, I95I). According to Knight-Jones it is the most generally abundant organism in British coastal waters and the North Sea, the greatest density he recorded for it being 3500 cells per $\mathrm{ml}$ in October 1946 from the Helford River, Cornwall.

Our records, covering a period of several years (Tables I \& 2, Appendix) amplify those of Knight-Jones and Walne and show that this species occurs commonly in the English Channel throughout the year from the surface down to $70 \mathrm{~m}$ (Table 2). It occurs also in oceanic water and has been recorded from oceanic stations from the surface down to a depth of $500 \mathrm{~m}$ (Table $\mathrm{I}$ ). In Table I of the Appendix (p. 297) its occurrences are listed other than for International Station EI and Plymouth Laboratory Stations L 2-6 from I7 September 1957 to 8 September 1959, the records for which are included in Table 2 (p. 297). This table includes densities at different depths sampled on one day at International Station Er.

\section{SUMMARY OF TAXONOMIC CONCLUSIONS AND DIAGNOSES}

We can now summarize in tabular form the more important facts ascertained or verified by us for the three organisms under discussion. From this table (p. 292) it will be seen that the organism formerly known as Chromulina pusilla Butcher agrees with Micromonas squamata in all salient features of internal organization, including plastid structure and form, the possession of one mitochondrion and in the position, relative to other cell organs, of the single flagellum. It differs in the absence of a scaly covering, in the absence of any trace of lateral hairs on the flagellum and in the very unusual relative proportions of the flagellum and its hair-point.

In contrast, Pedinomonas tuberculata differs from both the other species in the shape of nucleus and chloroplast, in the position and number of the mitochondria, in the presence of starch in definite grains, in the presence of 
canaliculi traversing the core of the pyrenoid, in the possession of tubercles beneath the surface membrane and of traces of calcite, quartz and cellulose indicated by $\mathrm{X}$-rays in association with the body membrane, and perhaps most of all in the morphology and mode of attachment to and within the cell, of the flagellum with its four large roots attached apparently to the chloroplast rather than to the nucleus and its very profuse array of exceptionally delicate hairs down the two sides. The resemblance between $P$. tuberculata and either of the other species is limited to very general features such as the plastid pigments, which are similar in all three in spite of the apparent difference of colour when viewed under the microscope, and to the possession of a single chloroplast and a flagellum directed backwards in swimming though arriving at this position in a somewhat different way. This degree of resemblance is perhaps sufficient to permit the placing of $P$. tuberculata within the same family or class as the other two species though not in the same genus.

It is not necessary for us to discuss the genus Pedinomonas further here, except to point out the strong probability that all the characters enumerated above as differentiating $P$. tuberculata from our other two species may need to be added to the specific diagnosis of $P$. tuberculata if the time ever comes to characterize this genus more fully in terms of its proper type species. With regard to our new genus Micromonas we are in no doubt that this can be

\section{Legends to Text-figs. $42-59$, all $\times 5,000$}

Micromonas squamata sp.nov.

Fig. 42. Cell stationary with flagellum curved round under body in characteristic position when at rest.

Fig. 43. Cell stationary with flagellum coiled twice round body.

Figs. 44,45 . Individuals swimming with the flagellum and body in the position characteristic for the species when swimming; point of origin of flagellum anterior.

Fig. 46. Early fission stage showing second short flagellum and pseudopodium-like filament; cell with two nuclei, pyrenoid, stigma and mitochondrion dividing.

Fig. 47. Examples of different sizes and shapes of isolated starch shells; for further description see p. 284 .

Fig. 48. Fission stage showing chloroplast divided.

Fig. 49. Double-fission stage producing four motile daughter-cells.

Fig. 50. Palmelloid phase with four daughter-cells.

Fig. 5I. Palmelloid phase with eight daughter-cells.

\section{Pedinomonas tuberculata (Vischer) Gams}

Figs. 52, 53. Individuals with the flagellum and body in the position characteristic for the species when swimming; point of origin of flagellum posterior.

Fig. 54. Cell with flagellum in characteristic position when cell is at rest.

Micromonas pusilla (Butcher) comb.nov.

Figs. 55, 56. Individuals with the flagellum and body in position characteristic for the species during rapid swimming; point of origin of flagellum lateral.

Figs. 57, 58. Individuals swimming slowly with flagellum directed forwards.

Fig. 59. Cell attached at clear end of body; body swinging round in circles from point of attachment. 
differentiated clearly from the type species of Pedinomonas ( $P$. minor), as described by Korschikov, on the light microscopy alone. We recognize, however, that while this applies with equal force to both our species of Micromonas, the decision to group these together as one new genus and not as two is to some extent arbitrary, depending on our decision, on grounds of convenience, to regard the differences between these two species as less significant than the resemblances and to treat such differences as specific and not as generic criteria,

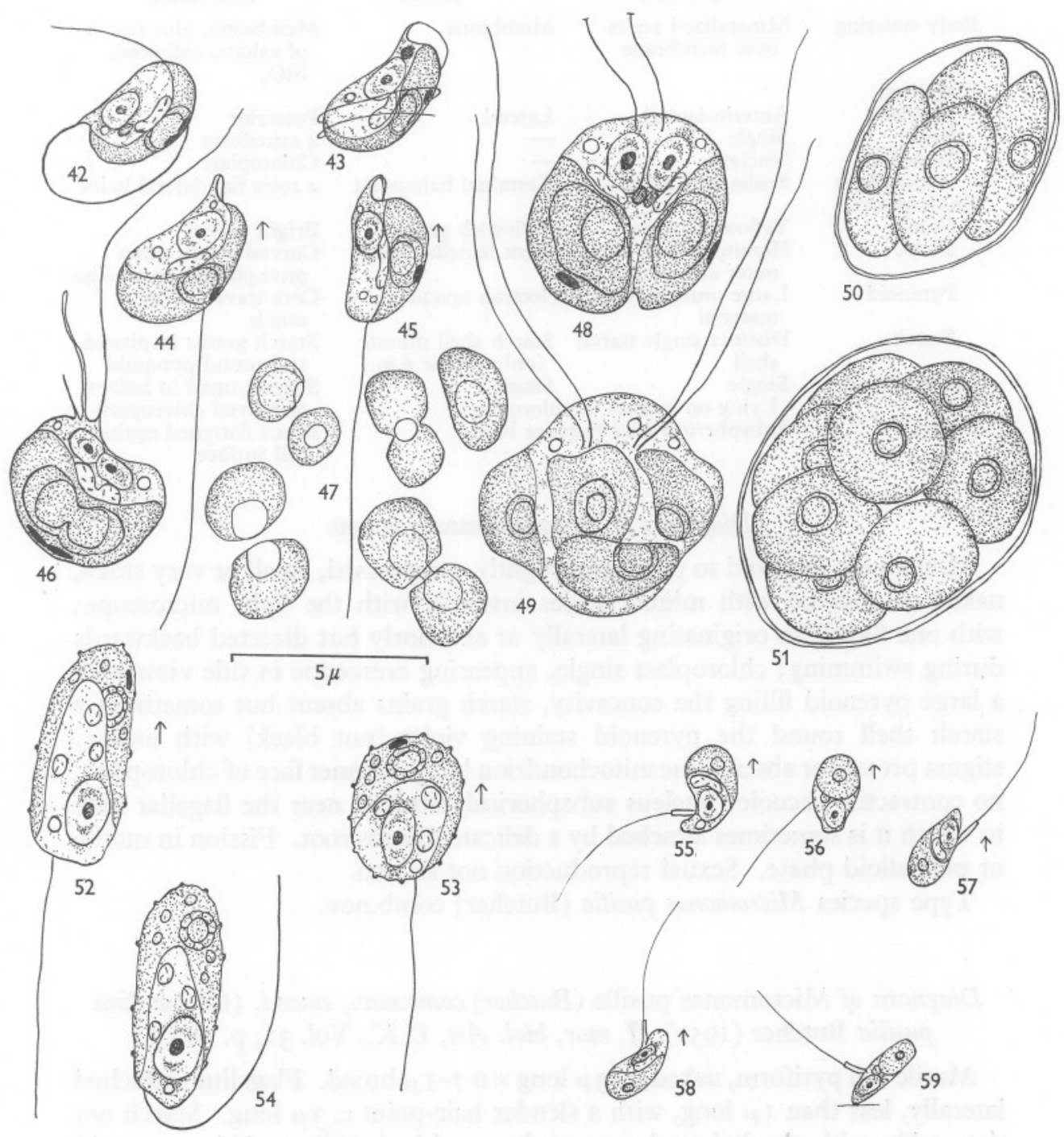

Text-figs $42-59$ 
as explained in the introduction. The way is then clear to summarize these conclusions still further by constructing formal diagnoses for the new genus Micromonas and for the two species which it at present contains.

TABLE OF MORPHOLOGICAL AND ANATOMICAL CHARACTERS AVAILABLE FOR DIFFERENTIATING THE THREE SPECIES UNDER DISCUSSION FROM EACH OTHER

\begin{tabular}{|c|c|c|c|}
\hline & $\begin{array}{l}\text { Micromonas } \\
\text { squamata }\end{array}$ & $\begin{array}{c}\text { Micromonas } \\
\text { pusilla }\end{array}$ & $\begin{array}{c}\text { Pedinomonas } \\
\text { tuberculata }\end{array}$ \\
\hline Body covering & $\begin{array}{l}\text { Mineralized scales } \\
\text { over membrane }\end{array}$ & Membrane & $\begin{array}{l}\text { Membrane, plus traces } \\
\text { of calcite, cellulose, } \\
\mathrm{SiO}_{2}\end{array}$ \\
\hline $\begin{array}{l}\text { Flagellum: } \\
\text { Attached }\end{array}$ & Anterio-lateral & Lateral & Posterior \\
\hline Roots & Single & - & 4 cruciform \\
\hline Joined to & Nucleus & - & Chloroplast \\
\hline Appendages & Scales and hairs & Terminal hair-point & 2 rows fine lateral hairs \\
\hline $\begin{array}{l}\text { Chloroplast: } \\
\text { Colour }\end{array}$ & Yellowish green & Yellowish green & Bright gre \\
\hline Shape & $\begin{array}{l}\text { Hemispherical with pi } \\
\text { outer curved surface }\end{array}$ & gment lamellae near & $\begin{array}{l}\text { Curved round other } \\
\text { protoplasmic organelles }\end{array}$ \\
\hline Pyrenoid & $\begin{array}{l}\text { Large uniform core of } \\
\text { material }\end{array}$ & electron opaque & $\begin{array}{l}\text { Core traversed by } \\
\text { canals }\end{array}$ \\
\hline Starch & $\begin{array}{l}\text { Distinct single starch } \\
\text { shell }\end{array}$ & $\begin{array}{l}\text { Starch shell minute } \\
\text { (only visible e.m.) }\end{array}$ & $\begin{array}{l}\text { Starch grains in plastid } \\
\text { and round pyrenoid }\end{array}$ \\
\hline Mitochondria & $\begin{array}{l}\text { Single } \\
\text { Lying on surface of } c\end{array}$ & $\begin{array}{l}\text { Single } \\
\text { chloroplast }\end{array}$ & $\begin{array}{l}\text { Several small in hollow } \\
\text { of curved chloroplast }\end{array}$ \\
\hline Nucleus & Subspherical near flag & ellar base & $\begin{array}{l}\text { Much flattened against } \\
\text { cell surface }\end{array}$ \\
\hline
\end{tabular}

\section{Diagnosis of Micromonas gen.nov.}

Motile cells ellipsoid to pyriform, slightly compressed, small or very small, naked or covered with minute scales invisible with the light microscope; with one flagellum originating laterally or anteriorly but directed backwards during swimming; chloroplast single, appearing crescentic in side view with a large pyrenoid filling the concavity, starch grains absent but sometimes a starch shell round the pyrenoid staining violet (not black) with iodine; stigma present or absent; one mitochondrion lying on inner face of chloroplast; no contractile vacuole; nucleus subspherical, situated near the flagellar base to which it is sometimes attached by a delicate fibrous root. Fission in motile or palmelloid phase. Sexual reproduction not known.

Type species Micromonas pusilla (Butcher) comb.nov.

Diagnosis of Micromonas pusilla (Butcher) comb.nov., emend. (Chromulina pusilla Butcher (1952). F. mar. biol. Ass. U.K., Vol. 31, p. 182.)

Motile cell pyriform, naked, $\mathrm{I}-3 \mu$ long $\times 0.7-\mathrm{I} \mu$ broad. Flagellum attached laterally, less than $\mathrm{I} \mu$ long, with a slender hair-point $c .3 \mu$ long. Starch not detectable with the light microscope but a thin layer round the pyrenoid 
thought to be a narrow starch shell visible with the electron microscope. Stigma absent.

Habitat in estuaries and the open sea round the British coasts. Neo-type culture Plymouth no. 27, isolated by $M$. Parke from the sea at position $50^{\circ}$ I5 $5^{\prime}$ N., $04^{\circ}$ I3 $3^{\prime}$ W. (I3 April 1950) at surface.

\section{Diagnosis of Micromonas squamata sp.nov.}

Motile cell ovoid with anterior pole depressed, $3-5 \mu$ diameter; the flagellum attached anterio-laterally, 3-3.5 times cell diameter in length. Surface of cell and flagellum completely covered with slightly mineralized plate-like scales of a spider's web pattern, 0.15 to $0.4 \mu$ in diameter; a few short stout curved hairs borne laterally on the flagellum but easily detached. Single starch shell demonstrable with iodine round the pyrenoid; a small stigma sometimes present on outer face of chloroplast close to the pyrenoid.

Habitat in brackish water. Type culture Cambridge no. $1965 / \mathrm{I}$, isolated by E. A. George from Brancaster Salt Marsh (salinity c. $15 \%$ ) in August I95I.

\section{GENERAL DISCUSSION}

Apart from the taxonomic conclusions only three general points need to be singled out for discussion. The observations on scale formation in Micromonas squamata constitute perhaps the most generally interesting contribution that this organism has made to botanical knowledge. Detachable surface scales are now known in great variety in pigmented micro-organisms of many groups but it is usually tacitly supposed that their place of origin is the cell surface itself, either on, in or immediately below the body membrane. Satisfactory direct evidence of mode of origin has hitherto eluded us, even in those species, notably of Chrysochromulina for which we have detailed electron microscopical information on the appearance and pattern of the finished scale. The observation in Micromonas squamata that the scales are here elaborated in the interior of the cell before being deposited on the surface individually from separate vesicles does not necessarily apply to any other flagellate. It is, nevertheless, strongly suggestive of a primitive and more plausible mechanism than any other yet suggested. It is therefore greatly to be hoped that precise observations on this particular matter may be obtainable from other genera.

Secondly, the various manifestations of hairs on the flagella on the two species described here offer many points of unusual interest. The presence of hairs as lateral appendages on certain flagella is well known in and characteristic of all the major heterokont groups (Xanthophyceae, Phaeophyceae Chrysophyceae, Saprolegniaceae, etc.) though not of the green algae as such. Nevertheless, reports claiming the presence of hairy flagella in individual 
genera of green flagellates have appeared in the literature more than once (e.g. Benešová, I949; Butcher, I959) and though these records vary very much in the degree of clarity with which the facts have been ascertained a few comparisons and contrasts can usefully be made. Thus the peculiar curved hairs encountered by us in Micromonas squamata bear a suggestive resemblance to hairs illustrated by one micrograph of Chilomonas paramecium (a colourless Cryptomonad) published by Pitelka \& Schooley (I955). C. paramecium is described by these authors as also possessing, on the same flagellum, another type of hair more nearly comparable in morphology to those commonly known as Flimmer in some of the heterokont groups. It is therefore possible that both in this Chilomonas and in our Micromonas squamata the peculiar curved hairs represent some entirely different category of appendage from ordinary Flimmer. A comparison based on only one micrograph reproduced at a very low magnification (17,000 in Pitelka \& Schooley's P1. 22 c) must necessarily be substantiated by fuller information before it can become more than a tentative suggestion. It would, nevertheless, be a matter of considerable interest if a real resemblance in this particular feature were to be found between two such apparently different organisms.

On the other hand, Pedinomonas tuberculata with its profuse garniture of very fine hairs is peculiar in several respects. The hairs here are individually far more delicate than those hitherto encountered in the heterokont groups, though in this particular character they may prove to be comparable with the Euglenoids, in some of which (e.g. Phacus, Manton, 1952) the hairs are also individually more delicate than average bacterial flagella. A marked difference from the Euglenoids is nevertheless provided by the presence in Pedinomonas tuberculata of hairs on both sides of the flagellum and also on the conspicuously posterior position of the flagellum both in point of attachment and in direction of movement. The usual position of the 'Flimmergeisel', in the heterokont types, as in the euglenoids, is forwards, even when, as in Dictyota, the cell may have become uniflagellate by suppression of one (the smooth) member of the pair (Manton, $1959 \mathrm{~b}$ ). The particular situation in P. tuberculata is thus at present without exact parallel.

A conclusion of some importance which these observations suggest is that outside the major heterokont groups the mere presence or absence of flagellar hairs cannot yet be used with the same precision as a phyletic guide as within the heterokont groups. Where hairy flagella are encountered among forms with chlorophycean pigments, notably chlorophyll $b$, there is reason to think that parallel evolution, possibly of more than one kind, may have taken place. If this were so, by no means all, and perhaps none, of the hairs encountered among green pigmented flagellates could be treated as homologous with those of the Phaeophyceae, Chrysophyceae, Xanthophyceae and Saprolegniaceae.

This may perhaps give point to the final comment that in very small 
organisms of the size range of those immediately under investigation in this communication, far greater care is necessary in formulating descriptions and in postulating phyletic affinities than has sometimes been used. The electron microscope as it can now be applied to the study of both morphology and internal structure has a uniquely important part to play in elucidating the facts regarding a region of the plant world about which very little has hitherto been known. It is of the greatest importance to clarity of thinking that hasty generalizations should not be made on insufficient evidence. If restraint is practised, however, it is to be hoped and indeed expected that when a greater number of individual taxa have been studied by comparable means some clearer general principles about how to interpret them may become available than we have at present.

Grateful thanks are due to Mr E. A. George of Cambridge for supplying the two cultures and for co-operating with information. We have to thank Dr G. Y. Kennedy of Sheffield for the pigment analyses, Miss I. Adams for assistance in the routine examination of samples and Mrs B. Hepper for testing Micromonas pusilla for its possible toxicity to fish. For help with the Latin diagnoses we have to thank Dr T. Christensen. We have also to thank Dr L. H. N. Cooper, Mr E. I. Butler, Mr D. Vaux and Mr A. Burd ('Sir Lancelot') for the collection of sea-water samples. Mention should also be made of the technical staffs of both Leeds and Plymouth for help in maintaining cultures, making preparations and completing the photography for publication.

\section{SUMMARY}

Pedinomonas tuberculata (Vischer) Gams has been investigated electron microscopically to the extent necessary to show that the generic name Pedinomonas cannot be used to include the flagellate formerly known as Chromulina pusilla Butcher.

A new genus, Micromonas, has been defined with $M$. pusilla (Butcher) comb.nov. emend. as the type species.

A second species of Micromonas, M. squamata sp.nov., has been described electron microscopically and with the light microscope. Special attention is drawn to one specific character of unusual interest, namely, the presence all over the flagellar and cell surface of an external covering of detachable platescales of characteristic pattern which have been shown to originate within vesicles in the body of the cell.

Attention is drawn to some of the comparative problems raised by the existence of lateral hairs of very different types on the flagellum in Pedinomonas tuberculata and Micromonas squamata respectively. 


\section{REFERENCES}

BENEŠOVÁ VL., I949. Fouets pleuronématés et disposition amphiconte chez l'Haematococcus pluvialis Flotow. C.R. Acad. Sci., Paris, T. 228, pp. 1883-5.

BRANDENBURGER, E. \& FreY-Wyssling, A., 1947. Über die Membransubstanzen von Chlorochytridion tuberculatum Vischer. Experientia, Bd. 3, pp. 492-3.

BUtCheR R. W., I952. Contributions to our knowledge of the smaller marine algae. F. mar. biol. Ass. U.K., Vol. 31, pp. 175-9r.

- 1959. An introductory account of the smaller algae of the British coastal waters. Part I. Introduction and Chlorophyceae. Fish. Invest. Lond., Ser. 4, 74 pp.

Fotт, B. \& Etru, H., 1959. Das Phytoplankton der Talsperre bei Sedlice. Preslia, Bd. 3I, pp. 213-46.

HARDER, R. \& Koch., W., I954. Über die Plastidenfarbstoffe von Pedinomonas (Protochloridales). Arch. Mikrobiol., Bd. 2I, pp. I-3.

KNIGHT-Jones, E. W., I95I. Preliminary studies of nanoplankton and ultraplankton systematics and abundance by a quantitative culture method. F. Cons. int. Explor. Mer, Vol. 17, pp. 140-55.

- 1952. Reproduction of oysters in the River Crouch and Roach, Essex, during 1947, 1948 and 1949. Fish. Invest. Lond., Ser. 2, Vol. I8, no. 2, 48 pp.

KNight-Jones, E. W. \& WaLne, P. R., I95 I. Chromulina pusilla Butcher, a dominant member of the ultraplankton. Nature, Lond., Vol. I67, p. 445.

Korschikov, A., I923. Protochlorinae, eine neue Gruppe der grünen Flagellata. Arch. russes Protist., T. 2, pp. 148-69.

Manton, I., 1952. The fine structure of plant cilia. Symp. Soc. exp. Biol., Vol. 6, 306-19.

- 1959a. Electron microscopical observations on a very small flagellate: the problem of Chromulina pusilla Butcher. F. mar. biol. Ass. U.K., Vol. 38, pp. 31933 .

- $1959 \mathrm{~b}$. Observations on the internal structure of the spermatozoid of Dictyota. f. exp. Bot., Vol. Io, pp. 448-61.

ManToN, I. \& Clarke, B., I956. Observations with the electron microscope on the internal structure of the spermatozoid of Fucus. F. exp. Bot., Vol. 7, pp. 416-432.

Parke, M., Manton, I. \& Clarke, B., I955. Studies on marine flagellates. II. Three new species of Chrysochromulina. F. mar. biol. Ass. U.K., Vol. 34, pp. 579-609. 1956. III. Three further species of Chrysochromulina. Vol. 35, pp. 387-4I4. 1958. IV. Morphology and micro-anatomy of a new species of Chrysochromulina. Vol. 37, pp. 209-28. 1959. V. Morphology and microanatomy of Chrysochromulina strobilus sp.nov. Vol. 38, pp. 169-88.

Pitelka, D. R. \& SChooley, C. N., I955. Comparative morphology of some protistan flagella. Univ. Calif. Publ. Zool., Vol. 61, no. 2, pp. 79-128.

VISCHER, W., I945. Über einen pilzähnlichen autotrophen Mikroorganismus, Chlorochytridion, einige neue Protoccales und die systematische Bedeutung der Chloroplasten. Verh. naturf. Ges. Basel, Bd. 56, pp. 4I-59.

1949. Pedinomonas Korchikov und eine neue Flagellatenklasse, Opisthokontae. Verh. int. Ver. Limnol., Bd. Io, pp. 504-Io. 


\section{APPENDIX}

TABLE 1. RECORDED DISTRIBUTION OF MICROMONAS PUSILLA (BUTCHER) MANTON \& PARKE

(Excluding Stations E I and L 2-6, September 1957-59)

\begin{tabular}{|c|c|c|c|c|c|c|}
\hline & Position & \multicolumn{2}{|l|}{ Depth } & \multicolumn{2}{|c|}{ Position } & \multirow{2}{*}{$\begin{array}{c}\text { Depth } \\
\text { (m) }\end{array}$} \\
\hline Date & W. & (m) & Date & N. & W. & \\
\hline 12. xi. 48 & $50^{\circ} 19^{\prime} 5^{\prime} \circ 4^{\circ} 10^{\prime}$ & 5 & 15. iii. $5^{8}$ & $47^{\circ} 20^{\prime}$ & $07^{\circ} 22^{\prime}$ & 0.5 , 10, \\
\hline 8. vi. 49 & $50^{\circ} 19 \cdot 5^{\prime}$ 0 $4^{\circ} 10^{\prime}$ & Io & & & & 20 , 100 , \\
\hline 29. ix. 49 & $50^{\circ} 19 \cdot 5^{\prime}$ 0 $4^{\circ} \mathrm{IO}^{\prime}$ & Io & & & & 200 \\
\hline I4. xi. 49 & $50^{\circ} \mathrm{I} 9^{\prime} 5^{\prime} 04^{\circ} \mathrm{I0}^{\prime}$ & I0 & & $47^{\circ} 30^{\prime}$ & $07^{\circ} 18^{\prime}$ & 20,100 \\
\hline 8. iv. 50 & $49^{\circ} 5 \mathrm{I}^{\prime} \quad 04^{\circ} 00^{\prime \star}$ & IO & r6. iii. 58 & $47^{\circ} 40^{\prime}$ & $07^{\circ} 13^{\prime}$ & $0.5,10$ \\
\hline I3. iv. 50 & $04^{\circ} 13^{\prime} t$ & 0.5 & & & & 20 \\
\hline 9. v. 50 & $04^{\circ} 54^{\prime \prime}$ & 0.5 & I8. iii. 58 & $47^{\circ} 46^{\prime}$ & $07^{\circ} 05^{\prime}$ & 20 \\
\hline 30. v. 50 & $04^{\circ} 13^{\prime}$ & 0.5 & I6. iv. 58 & $46^{\circ} 30^{\prime}$ & $08^{\circ} 00^{\prime}$ & 127 \\
\hline 13. vi. 50 & $06^{\circ} 20^{\prime}$ & 5 & I9. iv. 58 & $46^{\circ} 30^{\prime}$ & $08^{\circ} 00^{\prime}$ & 19 \\
\hline I4. vi. 50 & $07^{\circ} 26^{\prime}$ & 5,10 & 20. iv. 58 & $47^{\circ} 19^{\prime}$ & $07^{\circ} 23^{\prime}$ & 9,18 , \\
\hline I3. ix. 50 & $04^{\circ} \times 3^{\prime}$ & 5 & & & & 303 \\
\hline 29. v: 56 & $04^{\circ} 2 I^{\prime}$ & 2 & 2o. iv. 58 & $47^{\circ} 30^{\prime}$ & $07^{\circ} 18^{\prime}$ & 10, 19 \\
\hline 25. vi. 57 & Tamar Estuary & $\mathrm{T}$ & 20. iv. 58 & $47^{\circ} 38^{\prime}$ & $07^{\circ} 10^{\prime}$ & 10,225 \\
\hline 16. vii. 57 & $50^{\circ} 02^{\prime} \quad 04^{\circ} 22^{\prime}$ & 0.5 & 2I. iv. $5^{8}$ & $47^{\circ} 46^{\prime}$ & $07^{\circ} 05^{\prime}$ & Io, I9, \\
\hline $\begin{array}{l}\text { 6. xi. } 57 \\
\text { 4. iii. } 58\end{array}$ & $\begin{array}{l}\text { Tamar Estuary } \\
46^{\circ} 30^{\prime} \quad 08^{\circ} \mathrm{oc}\end{array}$ & 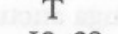 & & & & 125 \\
\hline 4.101. & 4630 & $\begin{array}{l}\text { I0, 20, } \\
0,500\end{array}$ & & & & \\
\hline
\end{tabular}

* Samples brought in by 'Sir Lancelot'.

$\dagger$ Neotype strain (Plymouth no. 27) of Micromonas pusilla isolated from this sample.

T Townet sample.

TABLE 2 SEASONAL DISTRIBUTION OF MICROMONAS PUSILLA (BUTCHER) MANTON \& PARKE

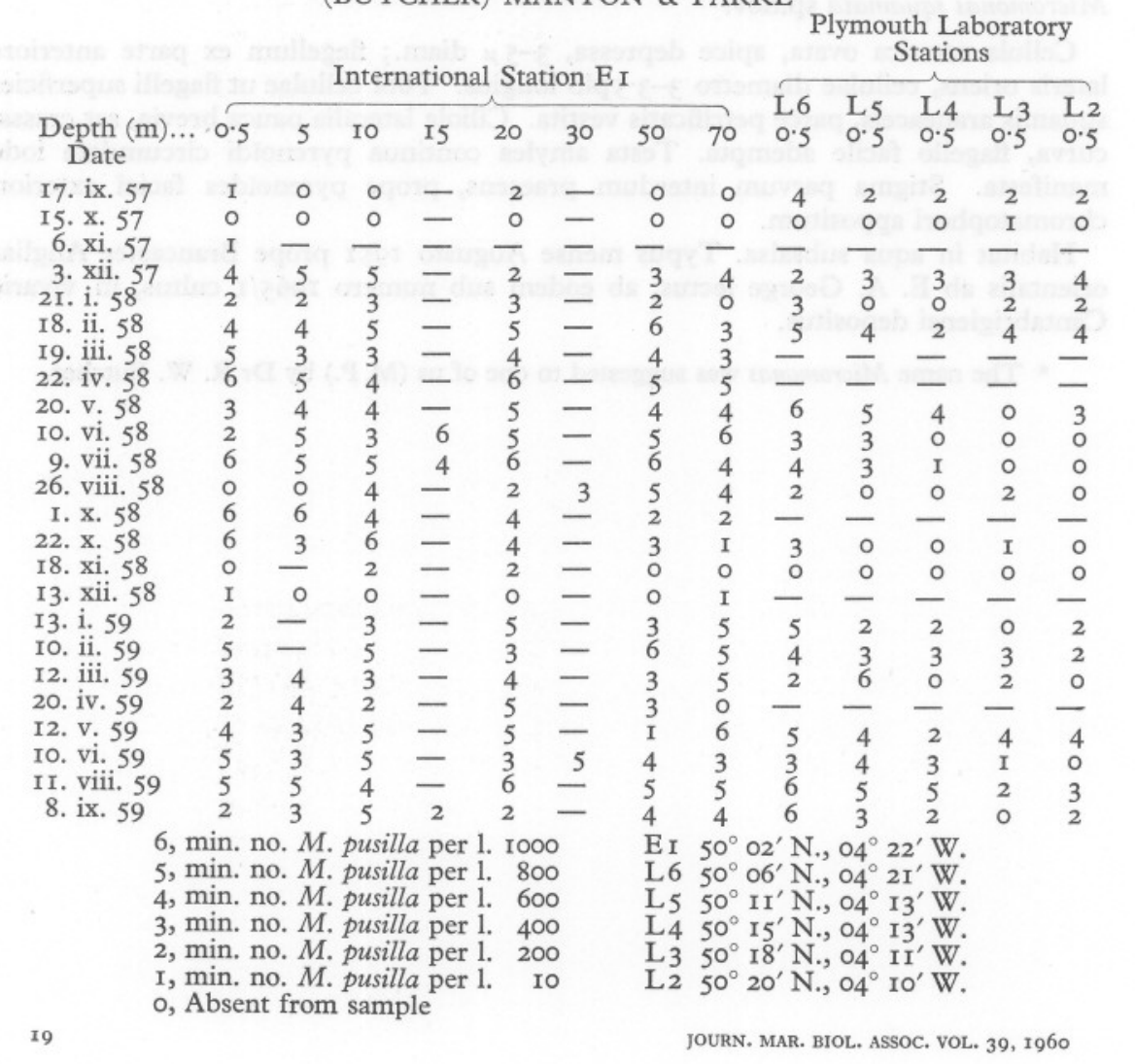




\section{FORMAL DIAGNOSES IN LATIN}

\section{Micromonas gen.nov.*}

Cellula erratica ellipsoïdes vel pyriformis, leniter compressa, parva vel minuta, nuda vel squamis minimis per microscopium luminarium non conspicuis induta; flagellum unicum e latere vel apice oriens, inter nandum retro deflexum; chromatophorum unicum a latere lunulare visum, pyrenoïde magno in sinu sito, amyli granulis nullis, sed testa interdum pyrenoïdi circumdata iodo violascente (non nigrescente); stigma praesens vel deficiens; mitochondrium unicum facieï cavae chromatophori appositum; vacuolum contractile nullum; nucleus subsphaericus prope basim flagelli situs, fibra subtili interdum illi conjunctus. Fissio in statu erratico vel in statu palmelloïde effecta; propagatio sexualis ignota.

Species typica Micromonas pusilla (Butcher) comb.nov.

Micromonas pusilla (Butcher) comb.nov., emend. (Chromulina pusilla Butcher (1952), F. mar. biol. Ass. U.K., Vol. 31, p. 182.)

Cellula erratica pyriformis, nuda, I-3 $\mu$ longa, $0 \cdot 7-\mathrm{I} \mu$ lata. Flagellum e latere oriens, vix I $\mu$ longum, seta tenui terminali ca. $3 \mu$ longa auctum. Amylum per microscopium luminarium non conspicuum, sed stratum tenue pyrenoïdi circumdatum per microscopium electronicum apparens pro testa amylea exili putatum. Stigma nullum.

Habitat in aestuariis ut in ipso mari oras Britannicas alluente. Neotypus die I3 Aprilis 1950 in summo mari lat. bor. $50^{\circ} 15^{\prime}$, long. occ. $04^{\circ} 13^{\prime}$ lectus, in Plymouth Angliae sub numero 27 cultus, postea in vivario Cantabrigiensi depositus.

\section{Micromonas squamata sp.nov.}

Cellula erratica ovata, apice depressa, 3-5 $\mu$ diam.; flagellum ex parte anteriore lateris oriens, cellulae diametro $3-3.5$ plo longius. Tota cellulae ut flagelli superficies squamis araneaceis, parce petrificatis vestita. Ciliola lateralia pauca brevia, sat crassa, curva, flagello facile adempta. Testa amylea continua pyrenoïdi circumdata iodo manifesta. Stigma parvum interdum praesens, prope pyrenoïdes facieï exteriori chromatophori appositum.

Habitat in aqua subsalsa. Typus mense Augusto 195I prope Brancaster Angliae orientalis ab E. A. George lectus, ab eodem sub numero $1965 / \mathrm{I}$ cultus, in vivario Cantabrigiensi depositus.

* The name Micromonas was suggested to one of us (M.P.) by Dr R. W. Butcher. 